\title{
Mao and Mediation: Politics and Dispute Resolution in Communist China
}

\author{
Stanley Lubman*
}

\begin{abstract}
Model Mediation Committee Member Aunty Wu
... If mediation isn't successful once, then it is carried out a second, and a third time, with the aim of continuing right up until the question is decided. Once, while Aunty $W u$ was walking along the street, she heard a child being beaten and scolded in a house. She went inmediately to the neighboring houses of the masses, inquired, and learned that it was Li Kuang-i's wife, Li P'ing, scolding and beating the child of Li's former wife. She also learned that Li P'ing often mistreated the child this way. After she understood, she went to Li's house to carry out education and urge them to stop. At the time, Li P'ing mouthed full assent, but afterward she still didn't reform. With the help of the masses, Aunty Wu went repeatedly to the house to educate and advise, and carry out criticism of the woman's treatment of the child. Finally, they caused $L_{i}$ P'ing to repent and thoroughly correct her error, and now she treats the child well. Everyone says Aunty $W u$ is certainly good at handling these matters, but she says, "If I didn't depend on everyone, nothing could be solved."
\end{abstract}

$\mathrm{W}$

E IACK MUCH ESSENTIAL KNOWLEDGE, not only about Chinese Communist legal institutions, but about Chinese society generally-how it is organized, how power is distributed and wielded, and the nature of even the most ordinary relationships. Such ignorance is dangerous, especially when China and the United States, and their perceptions of each other, remam tragically far apart. An analysis of China's institutions for resolving disputes can teach much about its dominant values and authority relationships.

This Article examines the resolution of disputes between individuals in China, relying on docunientary sources and on interviews conducted by the author in Mandarin with fifty Chinese emigrés in Hong Kong from 1965 through 1967.2 The Article has several primary goals. By

*A.B., 1955, LL.B., 1958, LL.M. 1959, Columbia University. Visiting Professor of Law, University of California, Berkeley, 1967-1968. This Article is the first in a series on Chinese law and administration. The author is grateful to the Rockefeller Foundation, the Foreign Area Fellowship Program, the Parker School of Foreign and Comparative Law, and Columbia University's Committee on Contemporary Chinese Studies for supporting the research on which this Article is based.

This Article was written in partial fulfillment of the requirenents for the degree of Doctor of the Science of Law in the Faculty of Law, Columbia University.

1 Kuang-ming Daily (Peking), Oct. 14, 1955.

2 "Only the availability, especially in Hong Kong, of significant numbers of former residents of the People's Republic makes it possible to fit together tentatively the disparate 
closely analyzing Chinese institutions that have hitherto been inadequately described in the West, it seeks to show how the disagreements, fights, and quarrels of ordinary people in China are settled. Further, it attempts to define Chinese Communist concepts of social conflict and social control, to deepen understanding of the Chinese institutions which manage conflict and exercise control, and to explore the functions of dispute resolution under Communism. Finally, this study compares traditional Chinese and Communist Chinese modes of dispute resolution. ${ }^{3}$

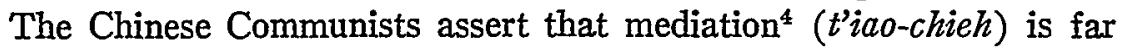

pieces of relevant data in order to see the system as a whole." Cohen, The Criminal Process in the People's Republic of China: An Introduction, 79 HARv. L. Ruv. 469, 476 (1966) [hereinafter cited as Cohen, Criminal Process].

A major excursus would be required to discuss in detail the methodology of emigré interviewing and the integration of information acquired from them with more conventional sources. Suffice it to say that emigré interviews should properly be considered only as secondary sources. They might be unreliable and would certainly teinpt readers' disbelief if they were not synthesized with information gleaned from documentary sources as is done here. My own experience and that of other researchers in Hong Kong indicates that the obvious and oft-discussed problems of emigre inaccuracy, fraud, and bias have been much exaggerated and are usually avoidable if the questioner concentrates on posing skeptical, cautious, and highly specific questions limited to imformants' personal experiences. Similar conclusions are reached and the problems discussed more fully in A. D. BARNETT, Cadres, Bureaucracy and Political Power in Comamonist China x-xx (1967). Many emigré responses add detail to a general picture that is quite apparent or easily deducible from conventional sources; but the interviews add irreplaceable detail, dimension, and color to our knowledge of China.

The emigrés" interviewed included eight men who had served in the public security (police) hierarchy, mostly in low-level posts in South China. The sample also included four graduates of Chinese law schools; several men who had worked in courts in various capacities; and former factory managers, engineers, technicians, labor union officials, skilled and unskilled workers, students, teachers, and government employees in offices concerned with econounic administration. Approximately one-fourth of the emigres interviewed were former members of the Communist Party or the Young Comnunist League.

The interviews relied on in this essay are my own, although $I$ have also compared and supplemented my findings with information in unpublished interviews conducted separately by Professor Ezra Vogel of the Department of Social Relations and the East Asian Research Center of Harvard University and Professor Victor $\mathrm{Li}$ of the Michigan Law School. I am grateful to both Professors Vogel and $\mathrm{Li}$ for freely making available to me the records of their interviews. Accounts of my own emigré interviews are maintained in my files.

3 This Article does not attempt to descrihe developments that may have occurred since the beginning of the "Great Proletarian Cultural Revolution" which has seriously disrupted almost every sector of Chinese society since mid-1966.

4 No attempt bas been made at the outset to define rigorously the processes denoted by "mediation." Mediation in any society comprises a wide range of attempts by third persons to settle disputes without formally imposing a decision on the parties; these activities extend from informal suggestions which the parties are free to spurn to decisions in form "suggested" but in effect binding. Rather than try to define the range of conduct any further, it seems preferable to proceed directly to analysis of the activities which the Chinese consider to be inediational; the range of activities will readily emerge. One reason for avoiding more rigorous definition at the outset of investigation is that it might overempha- 
superior to adjudication, which they consider coercive. ${ }^{5}$ This preference for mediation was evident when the Communists first ruled large numbers of people in the "newly liberated areas" before establishing the Chinese People's Republic in 1949. Since 1949, the Chinese Communists have continued to extol mediation and claim to use it far more extensively than

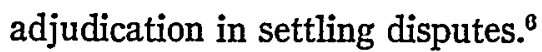

Before the Communists gained power, mediation had been the primary mode of dispute settlement for thousands of years in traditional Chinathat is, the China ruled by successive imperial dynasties until 1911, when the Ch'ing dynasty was overthrown. Confucianism, the dominant political philosophy in pre-Communist China, stressed the virtues of compromise, yielding, and nonlitigiousness. The organization of the imperial Chinese state, the operation of its governing institutions, and its traditional social nuclei-family, clan, village, and guild - combined to create pressures and institutions for extrajudicial mediation. The brief years of the Republic from 1911 to 1949 did not appreciably reduce the preference for mediation.

The forms and techniques of traditional mediation depended upon and expressed traditional Chinese values and authority relationships. But the Communists have sought to replace older values with their own, urging struggle where the Confucians counseled compromise. Furthermore, they have reorganized Chinese society by weakening or totally abolishing family, clan, village, and guild, which were both the institutions most likely to resist rapid change and the forums in which most disputes were resolved.

There is undeniably much mediation within the new collectivities for residence and work which the Communists have fashioned in reordering Chinese society. Several questions arise, however, concerning the Com-

size a too rigid contrast between two models-Chinese dispute resolution which aims at compromise and Anglo-American dispute resolution which facilitates winner-take-all. On American courts as agencies which impose compromise, see Coons, Approaches to Court Imposed Compromise-The Uses of Doubt and Reason, 58 Nw. U.L. REv. 750 (1964).

5 See, e.g., T'AI-HSING CH'Ü SSU-FA KUNG-TSO KAI-R'UANG [REPORT ON THE GENERAL Situation IN JUdicial WORK IN T'AI-HSING District] (1946) [hereinafter cited as T'AIHSING Report]; Yeh Ku-lin, Fully Develop the Role of People's Mediation Work for Serving the Construction of Socialism, CHENG-FA YEN-CHU,, No. 4, at 12 (1964), English translation in U.S. Consulate, Hong Kong, Selections from ChInese Mininuand MagaZINES [hereinafter cited as SCMM] No. 461, at 1-2 (1965). CमENG-FA YEN-CHIU has been China's only legal periodical since 1958, and hereinafter will be cited as PoLrticat-Least RESEARCH.

6See, e.g., Hsieh Chiieh-tsai Delivers Report on Work of Supreme People's Court at First Session of $3 d$ National People's Congress, U.S. Consulate Hong Konc, Current Background No. 751, at 6-7 (1965); Wang Kuang-li, Report on High Level Court Work in Honan Province, Honan Daily, Mar. 1, 1960, English translation in U.S. JonNT Publicatrons Research Service [hereinafter cited as JPRS] No. 6082, at 1, 4 (1960) (85\% of civil cases "settled by mediation"). 
munists' system for dispute resolution. How does Communist mediation differ in theory and practice from traditional mediation? What changes have the Communists wrought in the identity of the mediators, the processes of mediation, the mediators' standards and values, and the functions of mediation? To what extent have the standards and practices of the past conditioned, resisted, or overlapped those of the present?

This Article suggests that traditional and Communist views of social conflict and the modes for resolving conflict are mutually opposed and that the Communists, while continuing to use mediation, have substantially altered the traditional mode of mediating disputes. They have redefined the identity and role of mediators and have partially succeeded in transforming the process and functions of mediation.

The Communists have set themselves against the Confucian emphasis on compromise and the traditional Chinese avoidance of encounters with the government. They have infused into mediation absolute criteria of right and wrong rather than allowing mediation, as it once did, to seek a compromise that would not disrupt a delicate network of personal relationships within a narrow social context. The political functions of mediation are so pervasive that they frequently overshadow the settlement function by directing the mediators' perceptions of disputes and the standards used to resolve them. Political involvement has replaced passivity. In short, the Communists have incorporated mediation into their effort to reorder Chinese society and mobilize mass support to implement Party policies.

In demonstrating Chinese Communist conceptions of dispute resolution through analysis of the operation of mediational institutions, two problems arise: scarcity of conventional documentary sources and distorted perspectives. The American student of China may distort or fail to comprehend what he studies because he views an alien society in revolutionary turmoil from a distant and relatively placid vantage point. Even the student's questions may be unconsciously biased or hostile. Moreover, the student's discipline and training may further distort his perspective. Lawyers trained in Anglo-American or Western European legal traditions ask questions about China which all too often are based upon rigid assumptions about their own legal systems.

Perspectives may also be radically skewed by a narrow view of history. Every student of contemporary Chinese institutions is confronted with the problem of assessing the extent to which China's past affects China today. How opposed are Communist and Confucian values and institutions? How much intellectual and institutional continuity persists, overt or covert, conscious or disguised? In the West, the "sinological 
determinists" suggest that if you scratch a Communist, you will find a Confucian. ${ }^{7}$ At the other extreme, some observers, preoccupied with Communist-led social change, deny all continuity. The study of dispute resolution and law generally in Communist China is particularly troubled by the need to measure continuities and breaks in Chinese institutions.

The study of China, then, necessitates steering among some formidable intellectual obstacles; the student badly needs a direction finder that will aid comparison of traditional Chinese, Communist Chinese, and Western law and law-related institutions. The most reliable guide seems to be a commitment to determiming the functions of institutions. ${ }^{8}$ This functional approach requires identification of actors, their roles, and the values which they actually - as well as purportedly - maintain or suppress.

This Article consists of three parts. The first summarizes the characteristics of traditional Chinese mediation. The second analyzes the Communist node of dispute resolution by describing Communist conceptions of social conflict and examining the operation of mediation-the identity and role of the mediators, the qualities which the Communist Party desires them to possess, the standards they apply to disputes, and the social values and authority relationships which they represent and support. ${ }^{\circ}$ The third

7 The term "sinological determinism" is Joseph Levenson's. See his analysis in The Place of Confucius in Communist China, CHara Q., Oct.-Dec. 1962, at 1.

8 "Functionalism" has acquired many meanings and provoked many inconclusive debates among social scientists that need not be reviewed here. This Article tentatively employs an oversimplified "functional approach" which regards institutions as patterns of behavior by persons with roles whose purpose is to promote certain values; the functional emphasis aims at defining the relevant persons, their roles, their behavior, and the values they seek and serve for given organizations and institutions. This approach seems to commend itself particularly to the study of law in China both before and after Communist victory in 1949 since it aids the student to transcend narrowly legalistic views of dispute resolution, sanctioning, and social conflict generally. For a discussion of functionalism as it relates to comparative law, see J. Hatr, Comparative Law and Soctat Theory 104-110 (1963); J. Stone, Law and the Sociat Scrences $25-49$ (1966). See also Kaplan, Civil ProcedureReflections on the Comparison of Systems, 9 BuErato L. REv. 409, 431 (1960), quoting Prof. Ernst Rabel's cominents in Ass's of American Law Schoots, Summaruzed ProceEdings of the Institute in Teaceming of Internationat and Comparative Law 111 (1948): "Every comparison . . . needs a common denominator, a tertium comparationis. For me these fifty years past, this has always been the social purpose of the rules and the service of the concepts to this purpose."

9 This essay concentrates on resolution of disputes between individuals. These are not necessarily classified as "civil" rather than "criminal," since in China many minor offenses analogous to misdemeanors are sanctioned informally by the same persons who mediate disputes. See Cohen, Criminal Process, supra note 2, at 479. This essay is not concerned with studying dispute resolution between organizations such as economic enterprises because the Chinese Communists themselves have most frequently discussed and formally and publicly institutionalized dispute resolution between individuals.

It is extremely difficult to generalize about the processes used to resolve disputes between Chinese economic enterprises. The Chinese are said by numerous emigrés and Japanese visitors to use mediation. Courts are not used nor has a separate administrative 
part explores the functions of mediation in Communist China today and speculates on the relationships between traditional and Communist mediation.

I

DISPUTE RESOLUTION IN TRADITIONAL CHINA: A SUMMARY

In traditional China, ideology interacted with institutions to produce a characteristic mediational style of dispute resolution which is best described by focusing on two aspects: philosophical conceptions of disagency been charged with settling economic disputes. Emigré accounts indicate that very often enterprises and their superior agencies (government bureaus concerned with economic administration) engage in direct negotiations without third-party participation to settle disputes arising out of the contracts which implement economic plans. Sometimes, however, Party officials participate in settling disputes.

For a time the Chinese contemplated establishing a separate hierarchy of arbitration tribunaIs patterned after the Soviet tribunaIs (Gosarbitrazh). In 1956, the Ministry of Heavy Industry promulgated regulations on uniform contract clauses for enterprises subordinate to it; the regulations provided for fines for defective performance and nonperformance and plainly contemplated that an arbitral organization would soon begin to determine the fines. Ministry of Heavy Industry of the Chinese People's Republic, Temporary Basic Clauses on Contracts for the Supply of Products $\$$ 34, 43, in CHUNG-HUA JENIIIN KUNG-HO-KUO IMN-FA IS'AN-K'AO TS'AT-LIAO [REFERENCE MATERTALS ON THE CivII Law of the Chinese People's Republic) 243, 250-51 (Civil Law Teaching and Research Institute of the Chinese People's University, 1956).

However, arbitration organizations apparently have never become operative, if they were ever established at all. In 195\%, the failure to set up such organizations was criticized in Jen Chien-hsin, Strengthen the Work of Economic Contracts and Promote the Smooth Implementation of National Economic Planning, Politicat-Legar Researce No. I, at 31, 34 (1957). In 1958, an official textbook stated that China had no "arbitration organ," and that disputes arising out of contracts should be settled by "the parties themselves" or

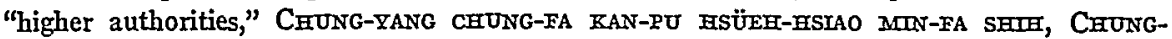
HUA JEN-MTN KUNG-HO-KUO MMNN-FA CHI-PEN WEN-TI [THE INSTITUTE OF CIVIL LAW Central Polimcal-Judictat Cadres' School, Basic Problems in the Civil Law of the People's Republic of ChINA (1958)], English translation in JPRS No. 4879, at 214 (1961). Recent legislation states that contract disputes shall be "arbitrated" (not mediated) by economic commissions (local planning bodies), whose decision must be executed by the People's Bank. Notice of the Central Committee of the Chinese Communist Party and State Council Relating to Strict Adherence to the Procedures for Basic Construction and to the Strict Performance of Economic Contracts, 13 CHUNG-HUA JEN-IInN KUNG-HO-KUO FA-KUEI HUI-PIEN [COACPIIATION OF LAWS AND REgULATIONS OF THE PEOPLE'S REPUBLIC of Chuna] 62 (1962-1963).

A recent development indicates the existence of divided opinions within China on whether or not a Soviet-type arbitration agency should be established and a continuing tendency, for the moment, to avoid creation of sucli an agency. Liu Shao-ch'i, Premier of the People's Republic and the major target of the Maoist-led "Great Proletarian Cultural Revolution" has recently been criticized for advocating that "the State need not do anything else apart from assuming the role of an 'arbiter' in disputes arising between industrial enterprises ...." Said the critic, "This relationship between the state and industrial enterprises is not different from the relationships which exist between capitalist states and industrial enterprises." Ching Hung, The Plot of the Top Ambitionist to Operate "Trusts" on a Large Scale Must Be Thoroughly Exposed, Kuang-ming Daily (Peking), May 9, 1967, English translation in SCMP No. 3948, at 1, 4 (1967). 
putes and their settlement and the institutions utilized for dispute resolution.

\section{A. Confucian Views of Social Conflict and Dispute Resolution ${ }^{10}$}

Confucianism, which dominated traditional Climese political thought, postulated the existence of a harmony extending througlout heaven and earth. On earth harmony was manifested in a hierarchical order that began with the emperor and extended downward to the lowest level of society. The aim of government, and indeed of all human relations, was to preserve natural harmony, which was the source of, and was expressed in, ethical behavior. Primary ethical rules lay in the $l i$, a variety of moral and customary principles for ceremonial or polite behavior. ${ }^{11}$ More concretely, $l i$ was a collection of "rules of belavior varying in accordance with one's status"12 which differentiated behavior according to age and rank in family and society. ${ }^{13}$ The function of $l i$ was "preserving status differences in a hierarchically organized society." ${ }^{14}$ The Confucians viewed law, $f a$, as a clumsy system of punishments directed only at strengthening the state and lacking proper regard for "an ordered world of peace, harmony and simple contentment," and the cultivation of the individual..$^{15} \mathrm{Fa}$ was associated with the radically different philosophical school of Legalism. This school regarded $l i$ and all ethical principles as irrelevant to government, whose essence was seen to lie in uniform and larsl regulation. $F a$ was further discredited when Legalist ideas were implemented by the harsl Ch'in dynasty. After Ch'in rule was dissolved in 210 B.C., Confucianism became the orthodox philosophy of the state.

In Chinese legal history from the Ch'in to the Ch'ing dynasty, overthrown in 1911, Confucian and Legalist strands of thought were interwoven; $l i$ was insufficient to govern the empire, and regulation was used

10 This brief discussion of philosophical attitudes toward disputes relies principally on T'Und-TSU Ca'ẗ, LAW and Socrety in Traditional Chona (1961) [hereinafter cited as T'Ung-tso Ch'Ü, Law and Socetety]; 2 J. Needram, Science and Civitization in Chera 526-32, 543-83 (1956); S. VAN der Sprenked, Legal Institutions in Manchu Chena (1962); and Bodde, Basic Concepts of Chinese Law: The Genesis and Evohution of Legal Thought in Traditional China, 107 Procendings of THe American PHIOosophical Socretx 375 (1963).

11 Bodde, supra note 10, at 383.

12 TUNG-TSU C $\mathrm{C}$ '

13 For a discussion of the specific differentiations in conduct dictated by the $l i$, see $i d$. at $230-39$.

14 Cohen, Chinese Mediation on the Eve of Modernization, 54 Carrf. L. Rev. 1201, 1208 (1966) [hereinafter cited as Cohen, Chinese Mediation].

${ }^{15}$ Schwartz, Some Polarities in Confucian Thought, in Confucuanssm IN Acroon 50, 56 (D. Nivison \& A. Wright eds. 1959). As one scholar has observed, the term fa connotes a "model or standard imposed from above, to which the people must conform." Bodde, supra note 10, at 379. 
to reinforce it. ${ }^{16}$ Much of the $l i$ was infused into substantive rules of law, thereby "Confucianizing" it so that, for instance, criminal penalties were differentiated according to status, membership in privileged groups like the literati, and position within the family. Further, Confucianism clearly influenced the interpretation of laws by officials charged with applying them. ${ }^{17}$ As Max Weber wrote, the Chmese magistrate "judged persons according to their concrete qualities and in terms of the concrete situation, or according to equity and the appropriateness of the concrete result." $" 18$

The dominant Confucian view of morality and law produced a characteristic view of disputes and their resolution. Disputes were viewed as disruptions of the natural harmony which linked individual, group, society, and the entire universe. As one scholar put it, "the spheres of man and nature were inextricably interwoven to form an unbroken continuum." Yiolding ( $\mathrm{jang}$ ) was virtuous because it prevented friction and disliarmony. ${ }^{20}$ Moreover, customary ethical rules of beliavior which emphasized status and the necessity of preserving group harmony greatly inhibited the assertion of rights and caused sucli claims to be regarded as disruptive violations of fundamental ethical rules. These philosophical tenets, the structure of Chinese society, and the operation of imperial governmental institutions combined to produce a striking preference for mediated settlement of disputes.

16 Bodde, supra note 10, at 382. "Even then, however, [the Confucians] remained Confucian in their insistence that the public enacting of law is not necessary in the ideal state, and that even in the inferior administrations of their own times, government by law should always be kept secondary to government by moral precept and example."

17 Yang, Some Characteristics of Chinese Bureaucratic Behavior, in Confuctanssm In Action 134, 153-54 (D. Nivison \& A. Wright eds. 1959): "Since legal imterpretation of an act in isolation from its situational context was disruptive of a social order in which the intimate personal relations of the primary group played a dominant role, soine adjustment was necessary. Only one way was possible: to supplant the system of formal rules by a situational orientation in which moral judgment prevailed over legal distinctions."

18 M. Weber, The Reirgion of China 149 (H. Gerth transl. \& ed. 1951). To the Chinese judge, quoting a precedent as a standard to be followed was like "making a mark on a moving ship to show where to recover a sword which has been dropped over its side into the river. . . Human nature is infinitely varied and there never is a case which is exactly the same as the one that has been decided before." Wang Hui-tsu, Precepts for Local Administrative Officials, in S. VAN DER SPRENKEx, supra note 10, at 137, 149.

10 Bodde, supra note 10 , at 375 . The notion of a continuum, it has been argued, contributed importantly to traditional concepts of dispute settlement. If all people view themselves as existing in an undifferentiated continuum, there are no criteria for judging such matters as "right" or "wrong" in a dispute; there is only the approval of the disputants relative to each other. See Northrop, The Mediational Approval Theory of Law in American Legal Realism, 44 VA. L. Rev. 347 (1958).

20 On the fundamental virtue of jang, which means "to have something to give up, and to give up in order to have" and which denotes "unodesty and circumspect and respectful conduct," see 1 M. Granet, Danses et Lígendes de la Chine Ancienne 88 n.1 (2d ed. 1959). 


\section{B. Traditional Chinese Institutions for Dispute Resolution: ${ }^{21}$ The Organizational Context}

\section{The Magistrates}

In traditional China a great gulf divided state and society. The formal apparatus of government extended downward from the emperor in Peking through provinces and smaller subdivisions to some 1,200 hsien or counties, the lowest governmental subdivisions, each with between 100,000 and 250,000 inhabitants. ${ }^{22}$ Magistrates, who were few in number, presided over the counties, directing and controlling all functions of government within their jurisdictions. These functions included maintenance of civil order, tax collection, supervision of public works, postal service, granaries, social welfare, education, religious activities, and administration of criminal and civil justice. Magistrates joined the elite quahified to serve by passing hiterary examinations on the Confucian classics; these examinations tested "whether or not the candidate's mind was thoroughly steeped in hterature and whether or not he possessed the ways of thought suitable to a cultured man and resulting from cultivation in literature." ${ }^{23}$ Although the magistrates were, at least upon their assumption of office, expert in the classics, they were untrained in administration.

Over the centuries the magistrates acquired a considerable number of clerks, runners, personal servants, and private secretaries, who supplied the main d'oeuvre of government: The clerks drafted, checked, and filed documents and records; the runners were court attendants, watchmen, policemen, guards, coroners, and turnkeys; personal secretaries coordinated the activities of clerks and runners and had key responsibilities for such activities as preparing for judicial proceedings, supervising trials, collecting information for tax records, and collecting taxes and grain tribute. The private secretaries were also administrative experts on speciahized matters such as law and taxation and supplied the magistrates with the knowledge of the detailed codes and precedents necessary to administer the law.

\section{The Gentry}

The magistrates were assisted very differently by the hiterary gentry, who had generally passed the same examinations as the magistrates but

21 This brief discussion of traditional Chinese society relies heavily, in addition to the works cited below, on two excellent discussions of administration during the Ch'ing

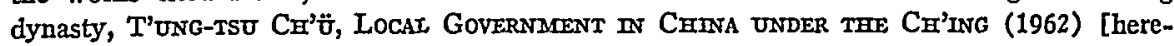
inafter cited as T'UNG-TSU CH'Ü, LOCAL GoverNMEENT], and KUNG-CHUAN HSinO, RuraL CHINA (1960).

22 KUnG-CHOAN HsIno, supra note 21, at 6.

$23 \mathrm{M}$. WEBER supra note 18 , at 121. 
held no office..$^{24}$ The gentry were members of the same elite as the offcials, sharing common values and a common intellectual background. Furthermore, the gentry and their families commanded great respect among the commoners. They enjoyed privileges under the imperial codes such as reduced liability for taxes and immunity from certain kinds of punishment and obligations.

The gentry were intermediaries between officialdom and the common people. Officials often needed their assistance in governing, and the gentry often needed the magistrates to maintain their prestige. On the other hand, the gentry also had personal and local interests to protect and sometimes resisted officials on such issues as taxation. When they were successful in modulating official demands on themselves and their localities, they eased the burdens which lay on the common people even though they did not generally act as spokesinen for China's vast population of tillers, laborers, artisans, and merchants. ${ }^{25}$

\section{Rural Headmen and Informal Leaders}

Within China's tens of thousands of villages, other persons besides the gentry exercised a small but significant quantuni of power over the rural inhabitants. These were rural headmen and village leaders appointed by the magistrate to deal with the county government on behalf of their village residents. Also appointed were heads of the ten-, hundred-, and thousand-household groups into which all the populace was formed under the pao-chia system; each ten-household unit under threat of collective responsibility was obligated to report crimes and the whereabouts of criminals. ${ }^{26}$ There were other informal leaders respected be-

24 Some persons acquired gentry status not by passing examinations, but by purchasing degrees and offices from the state, especially in the declining years of successive dynasties. Until the mid-nineteenth century, success in the examinations was the primary means of obtaining an official appointment, but after the Taiping Rebellion in 1851, sale of offices by the financially hard-pressed government became more important. See Ho PING-TI, THE Ladder of Success in I Iupertax Cemina 46-51 (1962).

25 Scholars differ considerably on the extent to which the gentry assisted the common people by exercising their influence with officials. Solne see the gentry as deeply involved with the welfare of the people in their area, e.g., Chung-Lr Chang, The Chinese Gentry 51-70 (1955), while others stress the gentry's selfishness and concern with their own personal interests, e.g., KUNG-CHUAN HSIAO, supra note 21, at 505-08. The Communists, not surprisingly, emphasize the gentry's oppression of the peasantry. One does not have to be a Communist, however, to recognize that China's peasantry was miserably poor, and that the gentry took advantage of their prestige and power to protect themselves against economic misfortune. The gentry's conduct was conditioned to some and often a considerable extent by their Confucian beliefs and the unseemliness of overt aggression. Conflicting interpretations of the gentry's treatment of commoners are plainly relevant to appraisal of their fairness in mediating disputes. See note 57 infra.

26 On the pao-chia system, see KUNC-CHUAN HsIao, supra note 21, at 43-83. 
cause of their age, learning, and reputation for probity, or feared because of their aggressiveness and unscrupulousness. ${ }^{27}$

\section{Families, Clans, Guilds, and Other Social Units}

The basic unit of traditional Chinese society was not the individual, but the groups to which he belonged. Most basic of all was the family, in which rules of customary behavior emphasized the precedence and authority of older over younger generations. The families themselves were organized into kinship groups or clans, a "transitional grouping between the family and village," ${ }^{28}$ which instructed members on Confucian morality, ${ }^{29}$ assisted poor and aged members, maintained schools and ancestral halls, and settled disputes among members. ${ }^{30}$

Yet another collective grouping was the guild, an organization of merchants or artisans in the same trade or craft. The guilds controlled prices, competition, training, and admission to callings. They also engaged in some charitable ventures and represented common commercial interests in dealing with government officials. ${ }^{31}$

Ordinary social and commercial relationships between persons unrelated to each other by family or common membership in a group also had a distinctive quahty-different from friendship-known as kanch'ing. ${ }^{32}$ The existence of kan-ch'ing between two persons meant that they had regard for each other and could ask favors from each other. In these relationships, persons did not want to lose "face"-their reputation for integrity and dignity. ${ }^{33}$ Personal relationships formed a tightly woven web.

27 On the "bare sticks" or "village bullies," see $i d$. at 454-62 and authorities there cited.

28 M. Yang, A Chinese Village: Taltou, Shantung Province 134 (1945).

$29 \mathrm{Liu}$, An Analysis of Chinese Clan Rules, in Confucran Theories in Actron 63, 68-72 (D. Nivison \& A. Wright eds. 1959).

30 On the functions of the clans, see generally M. Freedman, Lineage Organization in Southeastrern China (1958); Hut-chen Wang Liv, The Traditional Chinese Clan RUTES (1959); M. YANG, supra note 28, at 134-42.

31 On the guilds, see J. Burgess, The Guilds of Pering (1928); M. Fried, The Fabric of ChINESE SocIETy 146-53 (1953); MacGowan, Chinese Guilds or Chambers of Commerce and Trade Unions, 21 J. China Branch, Royal Astatic Soctety 133-70 (1886).

$32 \mathrm{M}$. FrIED, supra note 31, at 226, states: "Kan-ch'ing differs from friendship in that it presumes a much more specific common interest, much less warmth and more formahity of contact, and includes a recognized degree of exploitation." For examples and further analysis, see $i d$. at 102-09, 116-23, 144-45, 152-53, 170-76, 206-09, 223-28. B. GaLtTN, FistN Hising, Tatwan: A Chinese Village in Change, 303 n.2 (1966) adds that "it is basically a matter of structured obligation. The feeling or sentiment results from satisfied or disappointed expectations of appropriate behavior, and the expected behavior is behavior appropriate to the formal relationship of the two individuals within the social structure."

${ }^{33}$ On the concept of face, see Hu, The Chinese Concepts of "Face," 46 Arr. AvrmroPOLOGIST 45 (1944), quoted in S. VAN DER SPRENKEI, supra note 10, at 99-100; M. YANG, A ChINeSe Vintage, supra note 28, at 167-72. 
Family, clan, village, gentry, and officials dominated the individual. The pressure to maintain proper kan-ch'ing and "face" further conditioned his behavior. Moreover, institutions and ideology reinforced each other. For instance, a system was devised to indoctrinate the illiterate masses in the Confucian virtues. Lectures stressing piety, respect for elders and superiors, maintenance of harmony among neighbors, diligence, the necessity to instruct youth, and obedience to the law were given by officials, gentry, and local headmen at frequent compulsory meetings called "village pacts" or hsiang-yïeh, attended by the common people. Although the efficacy of these "sonorous platitudes" 34 in guiding the populace along virtuous paths may be doubted, and althougl the entire "village pact" system disintegrated well before the end of the Ch'ing dynasty, the use of these lectures illustrates the extent to which Confucian ideology permeated governmental techniques. Ideology combined with the institutional structure to create strong pressures for mediation of disputes.

\section{The Preference for Mediation ${ }^{35}$}

\section{The Perils of Litigation}

Most civil disputes were settled extrajudicially rather than through litigation in traditional China. ${ }^{36}$ Not only did the official philosophy stress the virtue of yielding and the superiority of noncontentiousness, but the administration of justice discouraged and sometimes ruined litigants. The magistrate's yamen, or office, was usually far from the disputants' residence. Magistrates were not law-trained experts but generalists often ignorant of the law and "corrupt, cruel, and lazy."37 Because the magistrates were inexpert and occupied with other functions of government, they relied heavily on their clerks and other under-

34 KUNG-CHUAN HSIAO, supra note 21, at 194.

${ }^{35}$ In addition to the other sources cited, this discussion relies on two excellent surveys of devices for resolving disputes in traditional China, S. VAN DER SPRENKEL, supra note 10; and Cohen, Chinese Mediation, supra note 14, at 1209-25.

36 See, e.g., T'ang-yin-pi-Shin, Parallee Cases mom under The Pear Tree 57-58 (R. Van Gulik transl. 1956); S. VAN DER SPRENKEI, supra note 10, at 79 (litigation "exceptional"); Cohen, Chinese Mediation, supra note 14, at 1216 ("[M] disposed of outside the formal legal system . . . in most instances disputes were resolved by informal mediation."); Ch'ï, Book Review, 35 PacIFIC Aframs 396, 397 (1962-63) (litigation "not uncommon," mediation "preferred").

${ }^{37}$ Cohen, Chinese Mediation, supra note 14, at 1212. The magistrate's lack of knowledge should not be overexaggerated. It has been observed that "only the generalist with proven practical ability was promoted," Yang, Some Characteristics of Chinese Bureaucratic Behavior, in Confuciandsm IN Actron 134, 145 (D. Nivison \& A. Wright eds. 1959) (emphasis added). However, Yang continues, "the impractical scholar, the bookworm, and the inept devotee of literary form were met most frequently at the low level of county magistrate" rather than at upper levels. $I d$. 
lings for assistance. The corruption and greed of these "tigers or wolves"38 was "legendary and frequently well-deserved." 30 The "customary fees" which had to be paid to the yamen employees imposed extraordinarily heavy burdens on litigants. ${ }^{40}$ Extraordinary, too, were the delays and "errors" which could beset a litigant hapless enough to fall afoul of a yamen employee. ${ }^{41}$ Furthermore, trials were humiliating for hitigants and witnesses and occasionally involved the use of torture to obtain evidence. ${ }^{42}$ Litigation was, in short, time-consuming, degrading, and costly. It was no wonder that " $[t]$ o involve someone in a lawsuit was a way of ruining him," ${ }^{43}$ and that, according to a Chinese saying, "[t]o enter a court of justice is to enter a tiger's mouth." 44 The perils of hitigation, widely publicized in popular lore ${ }^{45}$ undoubtedly restrained many persons froin

38 Cohen, Chinese Mediation, supra note 14, at 1213, quoting HUI-CHEN WANo LIU, The Traditional Chonese Clan Rules 155 (1959).

39 Cohen, Chinese Mediation, supra note 14, at 1213.

40 See the long list in TUNG-TSU CH'Ü, LOCAI GovERNMMENT, supra note 21 , at 47-48.

41 See, e.g., id. at 49: "The opening of a case could be purposely delayed if the defendant offered a clerk a bribe. Or the clerk charged with writing a deposition, the chao-shu, could make some changes in the records." (footnotes omitted). For accounts of how magistrates' employees could conspire to extort money under threat of involvement in litigation, see $1 \mathrm{~J}$. Doolitife, The Soctax LIFE OF THE CHINESE 305-06 (1865); A. H. SMTTH, VIILAGE LIFE IN ChINA 218-19 (1899); Brenan, The Office of District Magistrate in China, 32 J. China Brancer, Royar. Astatic Soctety 36, 49-50 (1897-1898).

42 For a description of the positions of witnesses and parties before the magistrate, see 1 J. Gray, China: A History of the Laws, Manners and Custgms of the Peopte

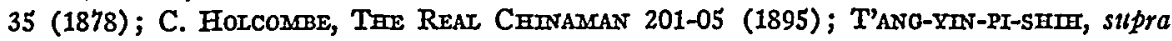
note 36 , at 55-58; Brenan, supra note 41 , at 51-52. The confrontation of differing and incompatible Western and Chinese notions of treatment of witnesses is amusingly illustrated in the account by Holcombe, a former American diplomat in China, of his disagreement with a Chinese judge who ordered a Chinese employee of a United States consulate to kneel while giving testimony, as was custormary:

As soon as [the witness] came into court, the Chief Justice called out: "Get down on your hands and knees."

"I beg your pardon," said I, "but this witness was not to be requested to kncel."

"I don't care anything about that," replied the Chief Justice; "he is Chinese and must obey Chinese law. Kneel down."

"You are violating a positive promise," said I, "the witness shall not kneel."

"Kneel down," said the Justice.

"Stand up," said I.

"Get down upon your knces," screamed the Justice.

"Leave the room," said $I$.

The frightened and bewildered witness obeyed me, and fairly ran from the room. Much sharp talk followed, the result of which was that the Chief Justice apologized, whereupon the witness was recalled and examined standing.

C. HOLCONABE, supra at 211.

43 VAN DER SPRENKEE, supra note 10, at 123.

44 R. DOUglas, CenIESE SocIety 104 (1901).

45 See, e.g., S. Gambie, North Chenese Vinlages: Social, Polmical, and Economac Activities Before 1933, at 246-47 (1963); A.H. Smetre, Chinese Characteristics 224-25 (1894). 
bringing suit at the magistrate's yamen and impelled them to settle disputes through extrajudicial mediation closer to home.

\section{Availability of Social Units as Dispute-Settling Forums}

A number of factors combined to cause disputes to be settled, as much as possible, within the basic nuclei of traditional Chinese society: The hazards of hitigation; widespread fear of involvement with government officials; the dominant ethic; and the primacy of the nuclei themselvesfamily, clan, village, and guild. Particularly in the settlement of disputes, these social units exercised considerable independence from the yamen. If disputes could not be settled within the unit, relatives, friends, and local leaders outside the group, but still closer to the disputants than the magistrate, would often resolve them by mediation. These groups generally strove to avoid involving government officials in quarrels between their members. ${ }^{46}$ Recourse to the magistrate without prior attempts to settle disputes within groups was actively discouraged and sometimes, as in the case of clans and guilds, prohibited by the group's internal regulations. ${ }^{47}$ In sum, "the local group generally required the parties to exhaust their remedies within the group before looking to the magistrate for relief." ${ }^{\prime 48}$

Generally speaking, disputes within families were settled by elders. While the authority of the pater familias was theoretically absolute, there was undoubtedly much mediation by older relatives, friends, and clan leaders-especially when the family was small. Disputes between members of a clan were settled by clan leaders and sometimes by other respected local leaders. ${ }^{49}$ Disputes within a village not coterminous with one clan were mediated not only by relatives, friends, and neighbors, but by official village headmen and unofficial leaders, whether gentry or other respected figures. ${ }^{50}$ Within the guilds, disputes between members were settled if not by friends, witnesses of a transaction, or middlemen, then by guild officers. ${ }^{51}$

40 On the clans, see M. FREEDMraN, supra note 30, at 115; Liu, supra note 29 , at 67 .

47 On the guilds, see S. VAN DER SPRENKEI, supra note 10, at 89-96 and sources therein cited. On the clans, see Hui-chen Wang Liu, The Tradimonat Chmese Cian Rules 15658 (1959).

48 Cohen, Clinzese Mediation, supra note 14, at 1223.

40 M. FreEdAsan, supra note 30 , at 115 . Sometimes disputes were mediated first by elders of a clan subdivsion; the subdivisions were based on descent from different sons of the common male ancestor considered to be the founder of the clan. If mediation was unsuccessful, first individual clan elders, then the clan council, would attempt to settle the dispute. C.K. Yang, A Chinese Vitiage in Eardx Comaronist Transition 97 (1959).

50 See, e.g., S. GaMBde, supra note 45, at 83-96; 1 D. KULP, Country LTFe IN Sotth

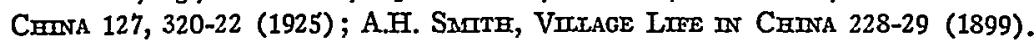

51 See, e.g., S. VAN DER SPRENKEI, supra note 10, at 92. 
The devices used to resolve disputes ranged from "completely private mediation at one end of the scale to public adjudication at the other, the one shading into the other almost imperceptibly as public opinion was felt to be more strongly involved." ${ }^{252}$ Often, mediators had to shuttle between the parties, talking separately with them and with other persons having knowledge of the matter in an effort to reach a mutually satisfactory compromise. One observer described the process thus:

First, the invited or self-appointed village leaders come to the involved parties to find out the real issues at stake, and also to collect opinions from other villagers concerning the background of the matter. Then they evaluate the case according to their past experience and propose a solution. In bringing the two parties to accept the proposal, the peacemakers have to go back and forth until the opponents are willing to meet halfway. Then a formal party is held either in the village or in the market town, to which are invited the mediators, the village leaders, clan heads, and the heads of the two disputing families. The main feature of such a party is a feast. While it is in progress, the talk may concern anything except the conflict. The expenses of the feast will either be equally shared by the disputing parties or borne entirely by one of them. If the controversy is settled in a form of "negotiated peace," that is, if both parties admit their mistakes, the expenses will be equally shared. If the settlement reached shows that only one party was at fault, the expenses are paid by the guilty family. If one party chooses voluntarily, or is forced, to concede to the other ... it will assume the entire cost. When the heads or representatives of the disputing families are ushered to the feast, they greet each other and exchange a few words. After a little while they will ask to be excused and depart. Thus, the conflict is settled. ${ }^{63}$

In the clans and guilds procedures akin to arbitration and adjudication were sometimes used if informal mediation had failed..$^{54}$ Settlement of a dispute by clan members might involve a formal hearing in the clan hall before a group of clan leaders and, perhaps, other respected members assembled for the occasion. ${ }^{55}$ Similarly, disputes between guild members were sometimes heard in the guild hall by a group of guild officers. ${ }^{50}$ On occasions like these, parties and witnesses would give testimony, and then a decision would be reached. Prevailing notions of dispute settlement emphasized that the "peace-talkers" or guild or clan leaders should try to bring the parties to compromise without imposing a decision on them.

52 Id. at 117.

53 M. YANG, supra note 28 , at $165-66$.

54 See S. VAN DER SPRENker, supra note 10 , at 85 and sources cited.

55 See, e.g., M. FreEdMaN, supra note 30, at 115; 1 J. GRAY, supra note 37, at 219-20.

56 For an account of such a hearing, see S. Gamale \& J. Burgess, Peknja: A Soctar SURVEY 194 (1921). 


\section{Mediation: Advantageous Even Though Imperfect}

These institutions for dispute settlement did not always function as smoothly and evenhandedly as idealized descriptions suggest. Just as the magistrate was often not a inodel Confucian gentleman, so the extrajudicial mediator was not always an exemplar of Confucian virtue. Often mediators stirred up disputes so that they could mediate them and be rewarded by successful parties. Furthermore, the informal justice obtained at the lrands of mediators was sometimes very unfair. Favoritism and bribes were common as were flagrant perversions of the mediation process, especially when a relatively wealthy and respected party was pitted against a much poorer opponent or when members of wealthy and powerful clan branches opposed less favored relatives. ${ }^{57}$ Because conflict was frequently embarrassing and disliked, parties anxious to end a dispute would sometimes agree to a compromise that was unsatisfactory to both. As a result, "[ $t]$ lie disagreement was merely driven below the surface and went on simmering, and the situation was ripe for explosion or provocation." 58 Finally, it was difficult for an unsuccessful disputant who thought he had been wronged by a village, clan, or guild decision to obtain redress from the magistrate, for lie was cliallenging not merely his opponent, but the social group which initially resolved the dispute. Public opinion in village, clan, or guild, and the threat of ostracism as punisliment for flouting it, were often strong enough to deter "appeals" to the magistrate. ${ }^{59}$

On the whole, lowever, extrajudicial dispute settlement by mediation

57 See, e.g., D. KuLP, supra note 50, at 322-23. See T'UNG-TSU CH'ن̈, LocaL GoverNIIENT, supra note 21 , at 189 . "True, there were gentry members who helped the innocent for the sake of justice. But more frequently their actions were motivated by nepotism or by financial gain." Scholarly opinion on the extent to which the gentry took advantage of their position is widely divergent just as it is on the extent to which the gentry were able to benefit the inhabitants of their areas. A considerable body of commentary by nineteenth century travelers is highly critical of the gentry's alleged impartiality. See, e.g., A.H. SArTH, supra note 41, at 219, who classes with the "village bullies" who instigated lawsuits and conspired with yamen clerks "the most expert of all this dreaded class," the "bullies" who had passed one of the hterary examinations and misused their status "to make use of this leverage as a means of raising themselves and of harming their neighbors. Any Chinese bully is greatly to be feared, but none is so formidable as the literary bully."

58 S. VAN DER SPRENREI, supra note 10, at 119-20.

50 On the strength of public opinion in villages, see, e.g., M. YANG, supra note 28 , at 150, stressing that the chief instrument of social control in his native village was "public opinion. . . . Social isolation is a terrible punishment." See also R. Douglas, Soctery IN ChINA 112-13 (1901). On similar pressures in the clan, see HUI-CHEN WANG LIJ, supra note 30 , at 157 . Even when civil cases were brought to the magistrate, he would sometimes encourage extrajudicial mediation by refusing to hear the dispute, "suggesting that the matter was too trifling for the courts and that the parties might best settle the inatter themselves by conciliation." Buxbaum, Chinese Family Law in a Common Law Setting, 25 J. Astan STUDIES 621, 623 (1966). 
offered considerable advantages to litigants and government alike. Mediation allowed parties to avoid expensive and possibly disastrous litigation while affording them "a method of terminating disputes that was socially acceptable in the liglit of the Confucian ethic and group mores." saving "face" and reaching a compromise satisfactory to both parties, disputants were better able to bargain with each other during mediation than in more formal proceedings. In addition, because mediation stressed the necessity of avoiding conflict, observing proper rules of behavior, and relying on the social group to compose differences, it provided auxiliary support for the dissemination of Confucian standards and values. Finally, extrajudicial mediation eased the government's burden of work and helped avoid friction between magistrates and the persons and groups in their jurisdiction.

\section{Traditional Mediation's Survival of Nationalist Rule}

After the Cli'ing dynasty was overthrown in 1911, and following an interregnum of warlordisin and civil strife, the Nationalists succeeded in establishing a central government in 1928. The Nationalists liad little time or good fortune in their brief attempt to build a modern governmental structure. Although they established organs of local government below the hsien level, ${ }^{61}$ in the countryside "the national government failed to substantially alter the traditional, decentralized pattern of local government in which the village political life operated largely by its own local power structure and was but weakly integrated into the system of central authority." 22 A modern court system was organized, but it never functioned effectively. ${ }^{63}$ Traditional, informal, extrajudicial mediation remamed the characteristic mode of dispute settlement througliout the years of Nationalist rule. ${ }^{64}$

\footnotetext{
${ }^{80}$ Cohen, Chinese Mediation, supra note 14, at 1223.

61 The measures are summarized in CH'IEN TUan-SHeng, The Governarent and Politics of Canta 226-32 (1961).

62 C.K. YaNa, supra note 49 , at 106. S. GaMrbe, sulpra note 45 , at $41-44$, noted slow but marked changes during 1929-1933 in villages due to increased government control.

63 Cr'men TUAN-SHeNG, supra note 61 , at 254 , notes that although legislation established hisien-level courts, most hsien by 1946 still had no courts, only judicial sections which were controlled by the magistrate. Even when courts were established, they may well have been subject to the magistrate's influence and control. See S. GaMble, Tino HsIEN 127 (1954). In general, judges were poorly educated, the courts were not easily accessible, and Nationalist Party influence was great. C\#'IEN TUAN-SHENG, supra note 61, at 254-55.

84 "[The Chinese people] used to consider going to court, that is bringing law suits before the hsien magistrate, as lacking in respectability. That sentiment still lingers to some degree. The lack of easy accessibility of the courts and the high cost of modern law suits also discourage an essentially poor people from resorting to bitigation to solve their disputes. Many disputes are settled out of court, sometimes to the advantage of both
} 
The Chinese Communists, as part of reordering Chinese society, have restructured the traditional institutions for settling disputes and have created new institutions. The changes have been far-reaching; in some ways Communist practice is not inconsistent with traditional patterns, but dispute resolution now bears the heavy imprint of Communist ideology and objectives.

II

\section{DISPUTE-RESOLUTION AND CHINESE COMMUNIST IDEOLOGY}

No contemporary Chinese institution is comprehensible without appreciating Maoist ideology's impact on it. Mao's views of society, social control, and social conflict have decisively influenced dispute resolution in China; to understand how disputes are settled, it is necessary to understand some salient characteristics of Maoism.

\section{A. Some Maoist Tenets and Purposes}

\section{Mobilizational Leadership}

An ideology is a view of the world and a program for changing it, and the Chmese Communists regard Maoism as nothing less. Mao's original concern was to mobilize the support of China's masses, especially the poor peasants who make up the overwhelming majority of China's people. Maoist ideology and the Chinese Communist political style evolved during the 1930's and 1940's in response to the need for a tiny minority of revolutionaries, isolated among hundreds of millions of politically inert peasants, to create a vast Party-led revolutionary army. Well before 1949 the Chinese Communists developed the technique of using "campaigns" or "movements" to arouse mass enthusiasm, increase production, and eliminate enemies. The later use of these techniques, as in the Great Leap Forward and the current "Cultural Revolution," illustrate the strength of the Communists" "guerilla heritage" and their commitment to leadership through mass mobilization. ${ }^{65}$

\section{The Party, the "People," and the "Enemy"}

The Communist Party controls both revolution and administration. The Party conforins to the Lenimist notion of a Comnuunist Party-a disciplined, elite body of professional revolutionaries leading the masses, especially the proletariat, whose dictatorship it is supposed to enibody.

parties, but more often to the advantage of the local gentry." CH'JEN TUAN-SHENG, supra note 61 , at $25 \%$.

65 See A.D. Barnetr, Cadres, Bureadcracy and Polmtical Power on Comanunist Chova 137-38 (1967); Johnson, Building a Communist Nation in China, in THe CoMnundsT Revolution IN Asta 47 (R. Scalapino ed. 1965). 
The Chinese version of the dictatorship of the proletariat distinguishes the "people," to whom the revolution belongs, from the "enemy." The "people" includes not only workers and peasants, but certain members of the bourgeoisie. ${ }^{68}$ The dictatorship of these elements is represented and wielded by the Party over the "enemies," who are the former exploiting classes and counterrevolutionaries in thought and deed. From the dichotomy between "people" and "enemy" flows a policy central to all methods of social control and resolution of social conflict: Problems within the "people" must be resolved by methods of "democracy," "persuasion," and "education," but problems between the "people" and the "enemy" must be resolved by methods of dictatorship, including "punishment according to law."

The distinction based on class between "people" and "enemy" is most strikingly illustrated by the concept of "class origin" (chia-t'ing $c h^{\prime} u$-shen): Every person in China is designated by his class origin. ${ }^{68}$ This designation indicates the economic position of each person's family and the extent of its affihation with the Nationalists at the time of Communist victory. So, persons are labeled as "landlords," "bourgeoisie," "[former Nationalist] bureaucrats," "rich peasants," or "upper-middle peasants"-all bad "class origins"-or as "lower-middle peasants," "poor peasants," or "workers" - all acceptable or good class origins. Supplementary personal classifications are also used; one variety labels some people as members of "the four bad elements"-landlords, rich peasants,

66 See Mao Tse-Tung, On the People's Democratic Dictatorship, in 4 Selected Wonks 411, 417 (Peking ed. 1961); F. Schurmana, Ideology and Organization in Comasunist China 109-10, 115-18 (1966); J.R. Townsend, Polmical Partictpation in Comanunist CHINA 66-67 (1967).

o7 See, e.g., MaO TSE-TUNG, On New Democracy, in 3 Selected Works 339, 351-52 (Peking ed. 1965); MaO TsE-Tung, On the People's Democratic Dictatorship, in 4 id. at 411; Mao Tse-Tung, On the Correct Handling of Contradictions among the People, in Cosaronist Cenna 1955-1959, at 273 (Anonymous ed. 1962).

The Chinese Communists have basically regarded law as an instrument of coercion and dictatorship to be used against the enemy, but Chinese Communist policies have had unany convolutions which cannot be traced liere. Party spokesmen expressed genuine but brief concern during several periods between 1954 and 1957 for expanding the reach and increasing the objectivity and technical level of legal institutions, and limited progress was made in adapting Soviet forms and procedures, especially in 1956. Policy changed abruptly after the famous "Hundred Flowers" of May, 1957, and since then has consistently emphasized that law is in the service of politics and the Party. However, in 1962, during an interlude of brief political relaxation, some less dogmatic views of law were published. A recent statement of policy is Chou Hsiu-min, Law is a Sharp Weapon of Class Struggle, People's Daily, Oct. 28, 1964, English translation in SCMP No. 3339, at 1 (1964). Periodizations are suggested in Cohen, Criminal Process, supra note 2, at 477-88; Leng, Post-Constitutional Development of 'People's Justice' in China, $6 \mathrm{~J}$. InT'x Comas's JurIsTs 103 (1965).

68 The literal translation of chic-t'ing ch'u-shen is "family background"; class, however, is the operative factor in the distinction. 
counterrevolutionaries, and "bad elements."69 These classifications entered in every person's dossier are taken as basic indicia of his loyalty and reliability and are the most important determinants of his career.

\section{The "Mass Line," Cadres, and "Activists"}

The technique embodying the Maoist approach to mobilization of the people-and administration generally-is the celebrated "nass line," a term denoting various techniques which the Party uses to measure and shape popular support for Party policy and to enlist participation in carrying it out. The Party maintains constant and close contact with the general populace, engaging in propaganda, discussion, persuasion, and exhortation to gauge mass reactions to policy and to lead mass action. ${ }^{\mathbf{7 1}}$ Mass discussion of policies imparts Communist ideology to the masses; mass action assists the Party to carry out policies it could not implement alone. The mass line thus expresses the Party's dependence on the niasses to accomplisi desired objectives. Illustrating the use of the mass line are the large meetings of peasants during the land reform campaign to denounce and punislı landlords and distribute their property and organizations of urban inhabitants to carry out public welfare schemes, sanitation work, and surveillance and control of counterrevolutionaries and criminals. The mass line embodies the Chinese Conlmunist preference for leading the masses through nonbureaucratic, if not antibureaucratic, measures of persuasion. In brief,

As conceived by the CCP, "going to the masses" does not mean dictating policies with obedience ensured by force. It is a long, complicated process that uses all available media to inform the masses, raise their level of understanding and consciousness, and ultimately translate Party policies into conscious popular action. ${ }^{\mathbf{7 2}}$

The mass line has important consequences for Chinese administrative style. It empliasizes mass participation in the execution, rather than in the formulation, of policy. Furthermore, the mass line blurs and sometimes obscures the distinction between governmental and nongovernmental organizations and activity. When the Party seeks direct contact

69 Persons classified as "bad elements" are subjected to considerable control and restraint: reports on their activites must be submitted periodically to the police, permission to travel is more difficult for them to obtain than for ordinary citizens, and they may be discriminated against in other ways. On the sanctions of "supervised labor" or "control" which are often imposed on "bad elements" by courts and police, see Cohen, Criminal Process, supra note 2 , at 491-92.

70 On the "mass line" see two excellent discussions, J.W. LEWIS, LEADERSBIP IN COMMrunist CHInA 70-100 (1964); and J.R. Townsend, supra note 66, at 72-74.

71 See Mao Tse-Tunc, Some Questions Concerning Methods of Leadership, in 3 SELECTED WORKs 117 (Peking ed. 1965).

72 J.R. TownSEND, supra note 66 , at $73-74$. 
with the masses, it employs the state apparatus as only one of numerous channels for contact-mass organizations and propaganda media are two obvious alternatives. The quality of participation which the mass line seeks to elicit is fervently enıtional rather than reasoned and deliberate. The Party employs persuasion and exhortation to promote voluntary compliance with policy, maintaining a wide range of sanctions for passivity or opposition. ${ }^{73}$ Notably, the nuass line politicizes much action in order to reach the masses and intensify their participation in the revolution-that is, "By investimg acts that are not in themselves political with an aura of civic obligation, the CCP opens up a much broader splere for the display of political activism." 74

The leader in implementing policy is the cadre. Cadres are Party members and other persons who hold paid administrative posts in the government hierarchy and in the mass organizations sucl as the Young Communist League, the All China Federation of Labor Unions, the Women's Federation, and the Students' Federation. ${ }^{75}$ For example, policemen, judges, factory managers, trade union chairmen, and Party secretaries are all cadres; most peasants and workers, unless they are Party members, are not. ${ }^{76}$ Cadres, constituting the nucleus of political leadership, ${ }^{77}$ are assisted by "activists," non-Party members strongly committed

73 See Vogel, Voluntarism and Social Control, in Soviet and Cennese Coanounism 168 (D. Treadgold ed. 1967).

74 J.R. TOWNSEND, supra note 66, at 81 . The mass line has heavily stamped Chinese administrative practice in other ways. For instance, the tentativeness of much Chinese administration is noteworthy. Administration in China is not a matter of imexorable fiat. Rather, decisions formulated at higher levels are usually stated very generally and often experimentally and made subject to qualification and modification according to local circumstances. Furthermore, decisions are often not implenented everywhere simultaneously, but first carried out in selected places often called "central" or "squatting" points. Only after these initial trials are proven successful is the policy decision applied elsewhere. Born of circumstances in which the Party experimented with untried policies whose acceptability to the masses was unproven, the Party's technique of administration is summarized in a favorite Party slogan "tien, hsien, mien," which can be freely translated as "starting at a single point, connecting points in a line, and finally extending the lines to cover the entire surface."

${ }^{75}$ An official definition quoted in F. Sceurasans, supra note 66 , at 165 , states that a cadre is "a worker in a state institution. Persons who work in state institutions or a department of production, capable of unifying and leading the masses to carry out Party and government policies and directory, to implement duties and programs promptly under the leadership of the Party and higher-level government institutions are cadres." The different types of cadres are analyzed in A.D. BARNETT, supra note 65, at 39-47.

"Mass organizations" have been usefully defined as "those secondary associations that recruit their members on the basis of common interests, characteristics, or occupation, and have national as well as local organization." J.R. TowNSEND, supra note 66, at 151.

${ }^{76}$ On the concept and role of the cadre, see J.W. LEWIs, supra note 70, at 185-95, and F. ScHURMANN, supra note 66 , at 162-72.

77 " $\mathrm{A}$ cadre is a leader who is supposed to lead in a certain way. The ideal cadre is supposed to act as combat leader, in intimate relationship with his followers, yet always responsive to higher policy. ..." F. SCHORAANN, supra note 66 , at 162. 
to Party policies and willing to act as the Party's unpaid propagandists and general assistants.

\section{4. "Thought" and the Theory of Contradictions}

Beneath mobilizational and administrative strategies aimed at the masses lies Maoism's fundamental concern with transforming the thouglit of individual men..$^{78}$ In the Maoist view, political action is incorrect unless it proceeds from and applies correct "thouglit," (ssu-ksiang). ${ }^{79}$ When the individual combines correct thought and action lie has arrived at a correct "standpoint," the ability to see things from a proletarian point of view. If thought is incorrect, then it must be "reformed;" reformed and correct thought and standpoint are essential to proper participation in the revolution. Once acquired, however, correct thouglit and standpoint are not static; like all things in the Maoist view, they contain internal contradictions which must be incessantly resolved through continuous and intense struggle in order to remain "correct." The thought and consciousness of men and their social classes must be clianged by "resolving their contradictions" through the use of tools of struggle, especially "criticism and self-criticism" and "thought reform."

Thouglit reform is no abstract theory; the Maoist concern with changing individual thought is evident in the mass movements and in the generally exhortative style of policy declarations and directives. Nor is the theory of contradictions an abstraction. ${ }^{81}$ Notably, in 1957 Mao linked the dichotomy between the "people" and the "enemy" to the theory of

78 The basic philosophical ingredients of Maoism summarized here are perceptively and systemically analyzed in J.W. LEWIs, supra note 70, at 35-69; F. SCEURMANN, supra note 66, at 17-57. On Mao's insistence on transforming the thought of individuals, see S. Schrata, The Politicat Thought of MaO Tse-Tung 52 (1963); Schwartz, Modernisation, and the Maoist Vision-Some Reflections on Chinese Communist Goals, Crina Q., Jan.-Mar. 1965, at 3, 11-12.

79 The standard translation of ssu-hsiang is "thought," but it is used in the Communist's lexicon to mean ideological thought. F. ScHURMaNN, supra note 66 , at xvii.

80 Thought reform has been described as follows:

Essentially, the technique consists in the usually temporary alienation of a single member from the group through the apphication of collective criticism. One member is singled out for criticism, either because of faulty ideological understanding, poor work performance, or some other deviance. He is not only subjected to a barrage of criticism from the nembers, but also joins in and begins to criticize himself. The avowed purpose of the procedure is to "correct" (kai-tsao) the individual. Under normal circumstances, the individual is "reintegrated" into the group after the "temporary" alienation.

Schurmann, Organization and Response in Communist China, 321 ANwals 51, 57 (1959). 81 Illustratively, Chinese legal cadres have debated the subtleties of using Mao's theory as their guide to disposition of criminal cases. See, e.g., Are All Criminal Cases to be Treated as Contradictions Between the Enemy and Ourselves? Are All Criminals to be Treated as Objects of Dictatorship? PortTICaL-Legal Researce No. 3, at 73 (1958), English translation in SCMM No. 142, at 10 (1958); Hao Chin-ch'ing and Wu Chien-fan, Defining the Two Types of Contradictions in Political-Legal Work and the Two Methods 
contradictions; conflicts between the "people" and the "enemy" are "antagonistic" contradictions, resolvable only by exercising the dictatorship of the "people," while conflicts within the "people" are "nonantagonistic" and can be resolved through the use of democracy. ${ }^{82}$

\section{B. The Development of Maoist Mediation}

The Maoist strategy for mobilizing the Chinese people was developed while the Communist Party was gaining control over great areas of rural China in the late 1930's and the 1940's. ${ }^{83}$ The impact of Maoism on Comnuunist law and dispute resolution is clearly traceable from that early period. A recent detailed survey of the characteristics of Chinese Communist justice before 1949 states that " $[\mathrm{P}]$ robably the most prominent feature of 'people's justice' developed during the Yenan period was the policy of the mass line," In several of the largest "newly liberated areas" from 1942 to 1944 legislation was promulgated requiring mediation in civil and some criminal cases ${ }^{85}$ and the press hailed the development of a new type of mediation. ${ }^{80}$

The decisive inpact of politics on mediational dispute resolution is clearly demonstrated by a report on judicial work in the T'ai-hsing district of Shansi Province in Northeastern China issued in $1946{ }^{87}$ The T'ai-lssing report hailed the improvenient in judicial cadres who had been guilty of "bureaucratism" and had been "divorced from the masses." After a major "rectification" campaign and intense self-criticism, many cadres had reformed their "thouglt" and matured their "viewpoint,"

of Handling Them, PolITICAI-LEGAL RESEARCH No. 2, at 25 (1963), English translation in JPRS No. 22989, at 52 (1964). For an application of Mao's theory of contradictions to family disputes, see Yang Ta-wen and Liu Su-ping, On the Function and Task of our Nation's Marriage Laze, PoliticaI-Legar ResearcH No. 2, at 38 (1963), English translation in JPRS No. 22989, at 87 (1964).

82 Mao, On the Correct Handling of Contradictions Among the People, in Comarunst China 1955-1959 273 (Anonymous ed. 1962).

83 In 1949 it ruled 90 million Chinese. J.W. LEwIs, supra note 70, at 6.

84 Leng, Pre-1949 Development of the Communist Chinese System of Justice, Crina Q., April-June 1967, at 93, 105.

$85 \mathrm{See}$, e.g., Decision on Mediation of Cases by District Offices (Draft), June 1, 1944, in 1 Hsien-hsing fa-LINg HUI-CHI [Collected Current Laws and Decrees] 323 (Chinch'a-chi Border District Administrative Committee 1946); Instruction on Strengthening Village Mediation Work and Establishing Work of Mediation and Handling [Cases] in Districts, in id. at 326. Leng, supra note 84, at $106 \mathrm{n} .65$, cites legislation for the ShensiKansu-Ninghsia and Shansi-Chahar-Hopei regions.

80 See, e.g., Comrade Ma Hsi-wu's New Method of Judging, Yenan Liberation Daily, Mar. 13, 1944; Use Mediation More and More Among the People, id., June 14, 1944. For a summary of developments at this time, see Leng, supra note 84, at 106-07.

87 The following discussion is based on the T'AI-HSING REPORT, supra note 5, at 2-13. $88 \mathrm{Id}$. at 2.

${ }^{89}$ Id. at 3 . The techniques of "thought reform" and "struggle" within the Party were 
offices to serve the masses and work among them. They had simplified procedures, abolished litigation costs, conducted on-the-spot trials, ceased to rely on documents and pleadings, and generally expanded the participation of the masses in "legal work." The report extolled development of mediation as the primary method of resolving civil disputes. Judicial proceedings were not conducive to mediation; it was better to go to where the dispute arose, to investigate the facts thorouglily, and to lold meetings on the spot to promote reconciliation.

The T'ai-hsing report stressed the ideological superiority of mediation, which was regarded as an efficacious instrument for "protecting the democratic interests of the great masses of people." Mediation, the report asserted, is a weapon of "struggle" against efforts to injure the masses; in reconciliating people it promotes unity..$^{90}$ To be correct, lowever, mediation must not merely aim at compromise and at pasting the parties together; it must be "principled," that is, grounded in policies and goals of the Party such as "caring for poor peasants" and encouraging freedom of marriage. ${ }^{91}$ Mediation must be particularly "principled" and unyielding in cases involving class warfare. For example, no deviation slould be permitted from the policy of "educating" landlords to reduce rents and interests, nor should peasants be encouraged to avoid contesting landlords' demands. ${ }^{92}$ Strict attention lad to be given to eradicating manipulation of mediation groups by landlords. ${ }^{93}$

The T'ai-hsing report also urged expanding participation of the masses in mediation work. It stressed the necessity of developing and relying on activists. The more activists and members of the masses who participated in mediation, the more people would be educated about Party policies and convinced that the Party was truly promoting the interests of the masses.94

given decisive form in the first great "Rectification" campaign conducted within the Party in 1942-1944. See B. Conipton, Mao's China: Party Reform Docunants 1942-1944 (1952).

90 T'AI-HSING REPORT, supra note 5, at 5-6.

91 Occasionally these policies conflicted. In one case, the wife of a "poor peasant" entered into a bigamous marriage. The cadres who mediated the dispute first tried to convince her to return to her first lusband, thereby manifesting their solicitousness for poor peasants like the husband. The wife refused, and the mediators decided to apply the principle of freedom of marriage, allowing her to remain with the spouse of her choice. However, the validity and importance of the first principle was maintained by requiring the second husband to compensate the first husband by giving him "some things." The cadres also thus demonstrated that they were willing to aid poor peasants by deed as well as by verbal expressions of concern. Id. at 7-8.

92 Id. at $8,13$.

93 Id. at 12 .

94 Multiplying contacts between Party and peasant masses, plainly one of the aims of mediation, clearly influenced decisions on the form of inediation. Experiments had been conducted with two different forms of mediation organizations: groups with fixed numbers 
Moreover, through mediation work the masses could be drawn into assisting cadres in other ways, such as by maintaining order and insuring that disputants abided by the decisions reached in their disputes. ${ }^{25}$

The report stressed that in mediating cases mediators had to "bring people around to a correct attitude" ( $t a-t^{\prime} u n g$ ssu-hsiang) which meant developing disputants' "positive factors." Thus, after a woman cadre who had had adulterous relations sought a divorce, mediators of her dispute with her husband stressed the "glory" of being a cadre. Because she feared losing her cadre status, this "positive factor" in her "thought" was used to educate her; her "problem" was "solved," and there was no divorce. Mediation should not be himited to the issues raised by the disputants; rather, the mediators should focus on "basic questions." So, when a wife who had committed adultery asked for a divorce, it was necessary not only to deny her request, but to convince her of the badness of adulterous relations. ${ }^{97}$

The relationship of the pohcies expressed in the T'ai-hsing report to the Maoist theory are self-evident. The report makes clear the Party's intent to use dispute resolution as a political instrument to mobilize support for the Communist Party among the peasants. The politicization of mediation is evident in the emphasis on class warfare, cadres serving the masses, changing the "thought" of disputants by changing their "attitude," cultivating "activists," and using "principled" dispute resolution to dissemmate Party policies and to demonstrate the Party's solicitousness for poor peasants.

The Communists clearly regard the several decades of their rule before they gained power over all China as the formative period of "people's mediation work," during which techniques were developed for infusing political themes and goals into dispute resolution. They hail the development of mass mediation as a significant accomplishment of this early period..$^{98}$ The Maoist commitment to using struggle, conflict, and changing

of participants led by cadres and activists and groups which varied with the dispute and the parties. Varying the inediators seemed preferable so that in a family dispute, friends and relatives could act as mediators, while in disputes involving cultivation of the fields, members of peasant associations could mediate. Varying the mediators, which also increased mass participation in mediation, was favored. $I d$. at 11-12.

95 For example, when a husband who wrongly suspected his wife of adultery threatened her with violence, the problem could not be settled satisfactorily by a court. Extrajudicially, the masses were able to convince the husband that his wife was innocent and that his suspicions were unfounded; they were also able to "guarantee" to the wife that her husband would not harm her. $I d$. at 11.

96 Id. at 8.

o7 Id. at 9.

${ }^{98} \mathrm{Ma}$ Hsi-wu, People's Judicial Work in the Shensi-Kansu-Ninghsia Border District During the Stage of the New Democratic Revolution, PortTICAL-LECAL RESEArCE No. 1, at $7,12-13$ (1955). 
of "thought" to aid pohtical development was expressed by innovations that affected dispute resolution. These early innovations were not forgotten after the party founded the People's Republic of China in October, 1949.

III

MEDIATION IN CHINA TODAY

After their victory in 1949, the Chinese Communists consolidated their control and mounted extensive programs of economic reconstruction and far-reaching social change. They substantially reintegrated a society that had been weakened and splintered for a century and then ravaged by decades of war. To understand dispute resolution in modern China, it is necessary to examine the Communist reorganization of Chinese society.

\section{A. Mediation in Residential Areas}

\section{The Organizational Context}

Hierarchies of power in China include the pyranidal apparatuses of state and Party, "mass organizations" such as those for youth and women, and networks of activists who serve as extensions of the formal organizations. These organizations can best be understood by assessing their impact upon the lives of ordinary Chinese. To illustrate the organization of Communist Chinese society and its effect upon dispute resolution, some features of an urban resident's life will be described in order to identify the persons with some quantum of coercive power in lis neighborhood whom he is likely to encounter.

The hypothetical urban resident, Mr. Lu, lives with his wife and two children in a large room in a city of several million people. The city is divided into districts ( $c h^{\prime} i$ i) of several hundred thousand persons; each district has organizations such as People's court, ${ }^{99}$ a procuratorial office, ${ }^{100}$ a public security ${ }^{101}$ (police) subbureau, and offices for supervision

98 The Organizational Law of the People's Courts of the Chinese People's Republic, Sept. 21, 1954, 1 CHUNG-HUA JEN-ILTN KUNG-HO-KUO FA-KUEI HUI-PIEN [COMTHATION of Laws and Regutation of the PeOple's Republic of ChINA, hereinafter cited as FKHP] 123, established a four-tiered system of courts, with the Supreme People's Court in Peking at the apex of a hierarchy that extended downward to "higher people's courts" at the provincial level (and in large cities), "intermediate people's courts" in provincial areas (and large cities), and "basic people's courts" in the hsien and municipal districts.

100 The Organizational Law of the People's Procuracy of the Chinese People's Republic, Sept. 21, 1954, 1 FKHP 133, provided for establishment of procuratorial organs at county, provincial, and municipal levels. Establishment of urban district procuracies was authorized "as needed." Id, art. 1.

101 For convenience, the Chinese term "public security" (kung-an) is freely rendered here as "police." The central police authority in a city is a "bureau;" there is one "subbureau" in each district. 
of economic and other routine urban activities. These district-led organizations are responsible to municipal-level superiors, but the Lus normally have hittle contact with district or municipal organizations. The Lus are governed most directly by the lowest-level representatives of a large apparatus of control and organization. The urban district is divided into smaller areas with populations of several tens of thousands; each smaller area has a police station and a "street business office." zations and their representatives that the Lus encounter in the course of their ordinary existence.

The police station, headed by a station chief and a deputy chief, has a complement of some thirty or forty men. Ten venture forth from the station as needed to investigate reported disturbances, crimes, and suspicious behavior; another ten check on the "ideological level" and political reliability of the other policemen and investigate suspected crimes with a particularly political tinge, sucl as sabotage or passing anti-Communist leaflets; and four or five men handle documents, such as the dossiers which are maintained for most adults in China. ${ }^{103}$ The remaining ten men are "houselold" or "census" patrolmen who patrol regular "beats" and are charged with close knowledge of the residents of their areas, particularly their comings and goings and their visitors. ${ }^{104}$

Corresponding to the police station in each area is the street business office, whicl is manned by full-time cadres who divide responsibility for such activities as distribution of food ration coupons, public health, propaganda, culture and education, women's work, registration of marriages, and mediation of disputes. Tlis street business office is not, however, the lowest-level agency of municipal government. In each street is a

102 The legislation establishing the police stations is Organizational Regulations for Public Security Stations, Dec. 31, 1954, 1 FKHP 243. The summary of police station organization is a composite based on interviews with former policemen from Kwangtung, Kwangsi, and Fukien provinces, supplemented by accounts of persons who visited or were detained at police stations.

The legislation establishing the street business offices is Organizational Regulations for Street Business Offices, Dec. 31, 1954, 1 FKHP 243.

103 Cf. Vogel, supra note 73, at 172: "All cadres, all intellectuals, all potential subversives, all students who have attended middle school, and all other people of importance have a permanent personal dossier which follows them everywhere they go. Not only does it follow, but it sometimes determines where they go, and how high. When eligibility for the Young Communist League or the Communist Party or liability to criticisun in a rectification campaign is at issue, the dossier often provides the answer. In the event of a misdemeanor, a previous black mark may well determine the severity of a citizen's punish. inent." The files of employed persons who do not live at their place of work are apparently kept there, although the files on their dependents would be kept at the police station in the area where they live.

104 See also F. SchuRararn, supra note 66, at 373: "He is generally not armed, is well acquainted with the people of the neighborhood, and has some of the qualities of a "local cop." " 
"residents committee" which is supervised by both the street business office and the police station, but is manned by activists rather than cadres. These activists also divide responsibility for public health, services such as nurseries and kindergartens, propaganda, culture, women's work, and minor welfare activities. ${ }^{105}$ Some members of the residents committees are probably also members of the street inediation committees described below. Beneath the residents committee, all residents are organized into residents "small groups" of fifteen to forty households ${ }^{106}$ which are led by activist "small group" leaders. Every household must be represented in a "small group" which meets regularly for political study and discussion and "criticism and self-criticism."107 The "small group leader" is supposed to observe closely the political attitudes and personal problems of the members of his group and maintain close cooperation with the local policemen and residents committee activists. ${ }^{108}$

Corresponding to the residents committee is yet another supplementary activist network of "security defense committees." tees have members in each residents small group who inust follow closely the activities of their fellow members and report to policemen and committee chairmen any suspicious doings, visits, comings, or goings. Other activist networks are the Young Communist League and the Women's Association, which are also organized in hierarchies that extend down to the street level. They transmit Party policies to the groups in Chinese society they claim to represent and organize support for the Party within those groups. For instance, the Women's Association has sought to indoctrinate women on their equality with men and to elicit their

105 The Residents' Committees are organized under Organizational Regulations for Urban Residents' Committees, Dec. 31, 1954, I FKHP 173. Their history and activities are described more fully in F. ScHuRMranN, supra note 66, at 374-80, and J.R. TowNSEND, supra note 66, at 158-65. In 1958-1961, when the Chinese experimented with urban communes which were intended to merge political and economic organization and use the labor power concentrated in the cities, the residents committees also supervised small scale manufacturing and repair establishments organized in the streets. Smce 1961 these have been deemphasized and many disbanded, but the residents committees seein to retain control over the relatively few economic activities that continue to operate, inainly sewing and repair shops.

${ }^{108}$ Organizational Regulations for Urban Residents' Committees, § 3(1), Dec. 31, 1954, 1 FKHP 173.

107 On small groups generally, see J.W. LEWIs, supra note 70, at 156-60; J.R. TowrSEND, supra note 66, at 174-76; Schurmann, Organization and Response in Communist China, 321 Annats 51 (1959).

108 On small group leaders, see Schurmann, Organization and Response in Communist China, 321 Amsars 51, 54 (1959).

109 The "security defense committees" were organized under the Temporary Regulations on the organization of Security Defense Committees, Aug. 11, 1952 FKHP 56. The Chinese "chilh-an pao-wei wei-yüan-hui" might be rendered inore hiterally as "committees for the protection of public order." 
participation not only in explicitly political campaigns like those against counterrevolutionaries, but also in campaigns to improve public health conditions in the neighborhood and to promote economic activities like the street industries organized during the urban commune movement of 19581960.110

Communist Party organization ${ }^{111}$ is embedded in eacl unit mentioned above, and the Party directs their activities through a vast Party hierarclyy which is parallel to, but distinct from and superior to, formal government hierarchy. Thus, in residential areas "small groups" of Party members are organized in each street or group of streets; these "small groups" are responsible to Party branches in the neighborhood; the branches are subordinate to general branches which are led in turn by the district and municipal Party committees. Each unit from branch upward is led by a Party committee headed by a Party secretary. Party small groups meet weekly for "criticism and self-criticism," and discussion about implementing Party policies in their organizations. These Party groups are intended to provide the leadership core for all activities. Thus, the chief of a neighborhood police station and many of the policemen would probably be Party or League inembers as would the head of the street busmess office, some of the cadres who work for it, and some members of the residents and mediation committees.

At their weekly small group meetings these Party members would discuss application of current Party policies to their work. ${ }^{112}$ For instance, if a nationwide campaign were being launched to remind the people of the need to engage in revolutionary struggle, Party members among the residents committee members and small group leaders in the Lus' street would discuss convening propaganda meetings of local residents. As a result, during the next week the Lus might be "invited" to attend a meeting at which "volunteer" story tellers would tell of past battles against the forces of Chiang Kai-shek and American imperiahism. ${ }^{118}$

The hypothetical $\mathrm{Lu}$ family will thus normally encounter in their neighborlood many representatives of state and Party power-their small group leader, security defense committee members, residents committee members, mediation committee members, cadres from the street business

110 See generally J.R. Townsend, supra note 66 , at $155-57$; C.K. Yand, The CHINesE Fandir IN the Chunese Revolution 117-36 (1959).

111 The literature on Party organization and leadership is voluminous. See generally J.W. LEWIs, supra note 70, at 101-44, F. ScHuRManN, supra note 66, at 139-62.

112 For a description of Party "organizational life" and "study," see A.D. BARNETT, supra note 65 , at 25-26, 30-32; Bamett \& Vogel, $A$ County, in id. at 161-65.

113 See, e.g., Revolutionary Stories Popular in Chinese Cities, NEw CHINA News Agencr, July 30, 1965, in SCMP No. 3511, at 23 (1965). The New China News Agency is Communist China's centralized news agency; its press releases are hereinafter cited as NCNA. 
office, policemen, and Party members and secretaries. ${ }^{114}$ The interrelation of most of the important people in the Lus' city can be schematized as follows:

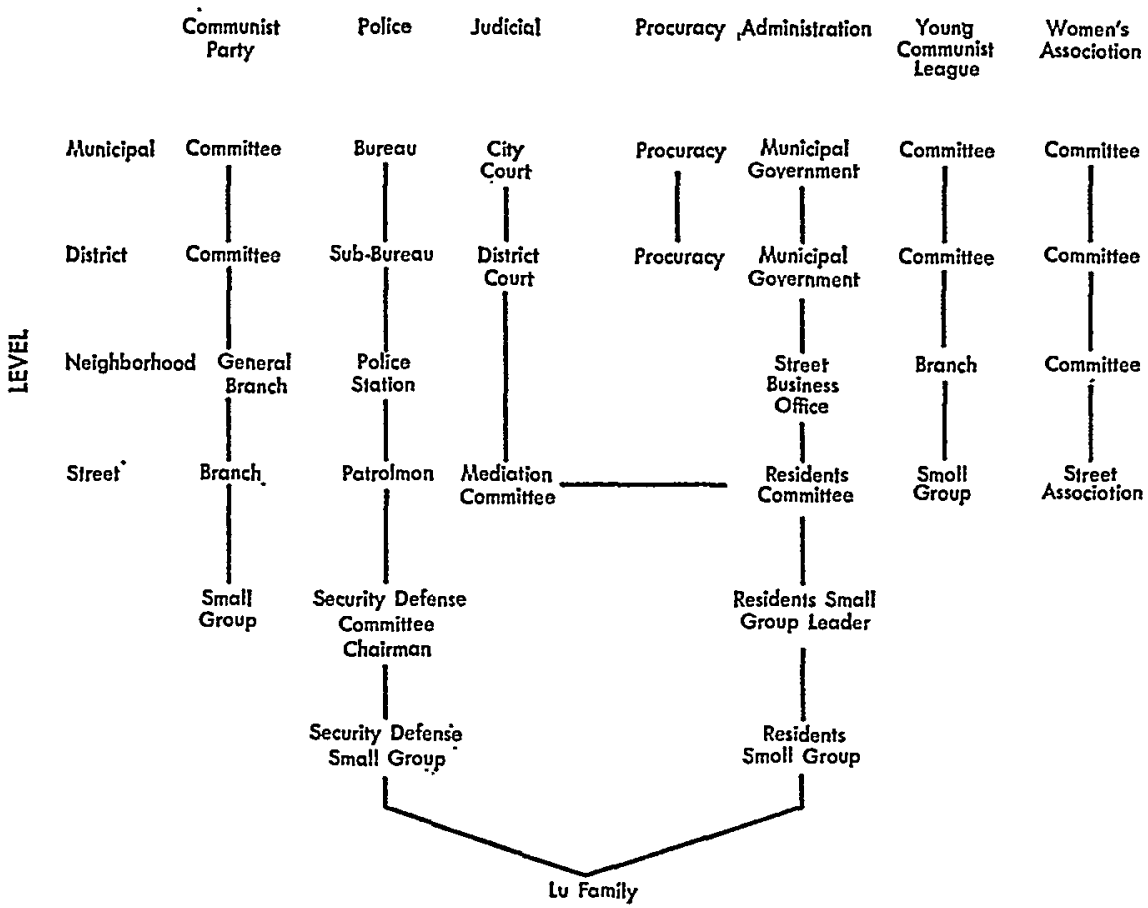

This apparently comprehensive system of urban control is what the Chinese Communists call "basic-level" organization. A caveat is necessary. The foregoing description is not an official model because it is based more on emigré interviews than on documentary sources. Further, although the control apparatus can work with an efficiency equal to any totalitarian system ever known, it often works very imperfectly-for example, there are many people in China's cities who are not properly registered with local police stations and whose movements consequently apparently go unobserved. However, the apparatus seems to have been quite successful in estabhshing and consolidating Communist control during the early years of the People's Republic and in maintaining that control, until the Cultural Revolution began. ${ }^{115}$

114 The Lus will also normally encounter other persons with authority. Mr. Lu will come into contact with them at his place of employment as will his wife if she is employed. Their children will also have significant contacts with such persons at their schools.

115 See Cohen, Criminal Process, supra note 2, at 490: "The patrolman assigned to the area of the residents committee works closely with the chairman and other responsible members of that committee, the security defense committee and the mediation committee, the secretary of the Communist Party umit within the residents committee, and the 


\section{The Mediators and the Process of Mediation}

All societies have developed institutions-distinctive patterns of behavior by identifiable persons with defined roles-for dealing with disputes and the social conflict they represent. In China, the organizational web described above institutionalizes dispute resolution as well as political control. In crowded Chinese cities disputes of all kinds are common: Children fight; neighbors argue about noise, communal sanitary facilities, insults fancied or real, minor debts and sales, and alleged damage to property; lodgers and landlords argue over unpaid rent or unexecuted repairs; husbands and wives argue over money, the children, innumerable domestic concerns, or divorce. If $\mathrm{Mr}$. Lu or his family should become involved in any such disputes, quite probably an attempt to resolve it would be made by at least one, and probably several, of the persons identified as important in the life of the Lus-small group leaders, security defense committeemen, members of residents and mediation committees, members of women's associations, street business office cadres, and policemen.

The following discussion demonstrates the role of "basic-level organization" in the settlement of disputes in residential areas. While it does not ignore other mediators, it focuses on the mediation committees, whose mediational style is very similar to that of other mediators in the residential control apparatus.

(a) Establishment and Purposes of Mediation Committees.-The new government of the Chinese People's Republic did not rush, immediately after victory in 1949, to establish a uniform system of mediation committees throughout the country like those already existing in the "old liberated areas." Some attempts were made to concentrate dispute settlement in the formal governmental hierarchy, but the courts were by no means the primary vehicles of mediation. In some cities "mediation sections" of full-time cadres were included in the municipal government in order to handle disputes which the urban population was bringing to otherwise occupied cadres for settlement. ${ }^{116}$ Mediation sections, which consulted with the district courts, ${ }^{117}$ were established in 1950 as part of the

secretary of the Communist Youth League unit. Together with the patrolman this group forms the local power elite and brings surveillance of the teeming urban masses down to the level of the individual household, a task that the police alone could not perform."

116 See, e.g., Laws and Decrees Combined with Facts to Carry ont Persuasion and Education: The Civil Affairs Bureau of the City of Wuhan in the Last Half-Year Mediated 246 Civil Disputes, Yangtze Daily (Hankow), Nov. 24, 1950.

117 Secretariat of the People's Court of Peking, JEN-MnN SSU-FA KUNG-ISO CHÜ-xü [Examples of People's Judictal Work] 47-8 (1950), a report on the work of the People's Court in Peking during the first year of Communist rule. 
district government in each of Peking's districts. In some cities groups of citizen mediators were set up within the newly establislied residents committees. ${ }^{118}$

Several years after 1949 the configuration of institutions began to take on the appearance it has today; a conscious decision seems to have been made to apply the mass line to mediation. In mid-1952 the Communist Party launched a nationwide campaign to "reform law" (ssu-fa kai-ke). ${ }^{119}$ Party spokesmen proclaimed that the courts lacked ideological and political purity and a proper class point of view. The large numbers of "retained judges"-those left over from the Nationahst regime-were accused of favoring guilty criminals with Nationalist affiliations, permitting counterrevolutionaries to go free, accepting bribes, rendering judgements contrary to the interests of the state, using "legal procedures" and teehnicalities to frustrate the will of the people, and behaving improperly to the masses. The new campaign sought ideological reform of judges througl "criticism and self-criticism" encouraged by the masses, dismissal or transfer of "unreformed" judges, and punishment of the counterrevolutionaries among them. Cadres and activists with the proper political attitudes and class point of view were installed in the courts. The extensive application of the mass line to legal work meant, as it had in the Conimunist-controlled areas before 1949, that judges would leave their offices and go to the people to mediate rather than adjudicate disputes.

During the campaign, legal cadres throughout China organized and led the masses in mediation. ${ }^{120}$ Judicial cadres were instructed to classify

118 See, e.g., Progressively Strengthen Mediation Work of a Mass Nature; Municipal People's Court Starts to Improve Mediation Organs, Fukien Daily, Nov. 24, 1952; The Mediation Snall Group of Yang Hung Middle Section, Liberation Daily (Shanghai), Nov. $17,1952$.

119 See, e.g., Reform of Judicial Work Under Planning by All Judicial Organs, NCNA, Aug. 17, 1952, in SCMP No. 401, at 17 (1952); Judicial Work Must Be Thoroughly Reformed, People's Daily (Peking), English translation in SCMP No. 401, at 19 (1952); Shih Liang, Report on Reform and Reorganization of People's Courts, NCNA, Aug. 22, 1956, in SCMP No. 404, at 5 (1952) (Shih Liang was Minister of Justice); CCP [Chinese Communist Party] Central-South Bureau Calls Conference to Discuss Judicial Reform; Comrade Teng Tzu-huti Gives Important Instructions, Southern Daily (Canton), Sept. 5, 1952, English translation in SCMP No. 412, at 20 (1952); Judicial Reform in CentralSouth Penetrates Deeply Step by Step, Yangtze Daily, Oct. 29, 1952, English translation in SCMP No. 454, at 19 (1952). For discussions of a more theoretical nature, see, e.g., $\mathrm{Li}$ Chien-fei, Criticism of the Supra-Class View of Law, HsüEH-HSI [STUDx, the theoretical journal of the Chinese Communist Party, which changed its name to RED FLAG in 1958] No. 7, at 13 (1952); Li Kuang-ts'an \& Wang Shui, Criticisms of the Old Legal Viewpoint, id. at 16.

120 For accounts describing the activities discussed in this paragraph, see, The People's Court of Peking's Third District Uses the Method of Collective Mediation to Clear Up Accumulated Cases, People's Daily, Aug. 18, 1952; Ho Ping-jan, People's Judicial Work 
cases according to subject matter and to select activist mediators from among groups particularly suited to settle the cases. For example, rent and housing disputes might be mediated by activist street residents, and commercial disputes ${ }^{121}$ by activist merchants. The cadres were then to lecture to the chosen activists on the specific policies they were to apply, such as those expressed $\mathrm{m}$ the marriage law. After this preparation, meetings of disputants were convened at which cadres and activists discussed the necessity of avoiding contentiousness and litigation. After these meetings, "mediation small groups" charged with settling the disputes were orgamized and led by the chosen activists. The groups were urged to conduct their work in close comrection with other organizations such as women's associations, peasants associations, residents committees, and labor unions. ${ }^{122}$ Cases that could not be settled by "small groups" were saved for large ineetings at which the parties were criticized, often severely, for not ending their disputes. Cases that remained unsettled went agam to the "small group," and finally, if still unsettled, to the judicial cadres. Occasionally, the "small groups" persuaded disputants to sign "patriotic pacts" in which they promised to avoid the conduct that had begun the dispute. Sometimes cases that could not be settled through mediation were settled quite drastically and used to set examples for the masses. In Shanghai, two woman workers accused their husbands of mistreatinent; the men were brouglit before a "large meeting for the pronouncement of judgment" (hsïan-p'an ta hui) at the women's factory. The ineeting was conducted by the chief judge of the local district court and attended by fellow workers, the factory chief, and union officials; divorces were announced, and the two men were given prison sentences for mistreating their children. ${ }^{123}$

The new mediational institutions for dispute settlement received much praise. ${ }^{124}$ Mediators were extolled for going directly to the disputants

Must Rely on the Masses; Introducing the Work Method of Collective Mediation of a Mass Nature of the Peking People's Courts, Kuang-ming Daily (Peking), Oct. 25, 1952.

121 China's economy was not yet nationalized in 1952.

122 See, e.g., San-te Li Mediation Small Group Carries out the Mass Line; Reconciles a Worker Couple [in a] Divorce Case, News Daily (Shanghai), Jan. 23, 1953; Ch'en Kuanhua \& Chiang Cheng-chieh, How Mediation Work Was Carried Out in Chi-shan Hsiang, Kunming, New China Daily (Chungking), June 11, 1953; Ch'en Kuan-hua, Excellent People's Mediation Committee Member Li Jui-neng, id., June 11, 1953.

123 See, e.g., Firmly Put Into Effect the Spirit of the Masses Dealing with Cases: Court Pairs with Mediation Small Groups in Nationally-Owned No. 5 Cotton Mill to Handle More than Thirty Accumulated Cases, News Daily (Shanghai), Nov. 19, 1952. For another case of the same type, see Organize the Masses to Handle Disputes within the People; Municipal People's Court Does a Key Point Experiment in Sung-Shan District, id., Oct. 26, 1952.

124 See, e.g., The Mediation Middle Section of Yang-heng Chung-che, Liberation Daily (Shanghai), Nov. 17, 1952; Closely Relying on the Masses, Do People's Judicial Work 
to investigate the causes and circumstances of disputes. The "political consciousness" of masses and cadres alike was raised, and mediation work developed new activists. Mediation avoided litigation, which was objectionable because it caused bitterness and interrupted production. But there were problems. ${ }^{125}$ Mediation was disorderly and carried on with insufficient preparation, and the courts frequently neglected to assist the mediators. Links between policy and mediation were too often left ambiguous: Divorces sought by wives were erroneously denied despite the policy of liberating "oppressed" wives; capitalists and others who injured state property were leniently treated in a spirit of compromise; and cases were often settled without attention to policy, solely for the sake of reconciliation. ${ }^{126}$ At the other extreme, complaints were voiced against cadres who forced disputants to settle. ${ }^{127}$ Cadres were urged to attend to these problems and to systematize their work.

After the mediation "small groups" and committees were extended across China in conjunction with the "legal reform" movement, their purpose, as articulated in Peking, began to change. New and different links between mediation and policy were made explicit. After China's first Five-Year Plan began in 1953, the Communist Party increasingly emphasized the new tasks and obligations that lay on China's people. A new stage in China's development was proclaimed. Now, instead of merely repairing the damage wrought by generations of war, China was embarking on a phase of economic construction hailed as having great significance for all activities including legal work and mediation. In early 1953 , a conference on legal work was called. Unlike prior meetings and announcements, the conference did not emphasize "legal reform." Rather, it looked to the future, for Vice Premier Tung Pi-wu

Well; An-shen Ward Mediation Small Group Acquires Preliminary Successful Experience, id., Oct. 29, 1952; Ho Ping-jan, People's Judicial Work Must Rely on the Masses; Introducing the Work Method of Collective Mediation of a Mass Nature of the Peking People's Courts, Kuang-ming Daily (Peking), Oct. 25, 1952. Organize the Masses to Handle Disputes Within the People; Municipal People's Court in Sung-shan District Does a Key Experiment, Liberation Daily (Shanghai), Oct. 26, 1952; Strengthen Mediation Work, Implement Giving a Mass Nature to Judicial Work, News Daily (Shanghai), Jan. 12, 1953.

125 For discussions, see, e.g., Strengthen Mediation Work, Inplement Giving a Mass Nature to Judicial Work, News Daily (Shanghai), Jan. 12, 1953.

126 On this last error, see Instructions of the People's Government of Sinkiang Province on Establishing District and Hsiang Mediation Organizations and Developing Mediation Work among the People, Sinkiang Daily, Apr. 15, 1953.

127 See, e.g., People's Judicial Work Must Rely on the Masses; Introducing the Work Metrod of Collective Mediation of a Mass Nature of the Peking People's Courts, Kuangming Daily (Peking), Oct. 25, 1952; Closely Relying on the Masses, Do People's Judicial Work Well; An-shen Ward Mediation Small Group Acquires Preliminary Successful Experience, Liberation Daily (Shanghai), Oct. 29, 1952; Progressively Strengthen Mediation Work of a Mass Nature; Municipal People's Court Starts to Improve Mediation Organs, Fukien Daily, Nov. 24, 1952. 
said, "It behooves us to strengthen the work of legal construction on the prevailing foundation of legal reform, in the effort to ensure the completion of national economic construction." ${ }^{\text {2128 }}$ Methods had to be devised to strengthen the support which legal work offered to economic construction; mediation was one such method, and draft regulations on the organization of mediation committees were presented to the conference. ${ }^{120}$

In March 1954, "provisional rules" were promulgated in Peking for the nationwide organization of People's Mediation Committees. ${ }^{130}$ The committees were elected to "make timely settlement of civil disputes, strengthen education of the people on patriotism and observance of the law, and create unity among the people in order to benefit the people's efforts for production and national construction."131 The committees were to be subordinate both to the "basic-level" government and "basiclevel courts," as predecessor committees had been for several years. The committees were to settle "civil disputes and minor criminal cases," and "carry out propaganda and education on national policies and laws."132

Mediation committees with three to eleven members were to be established in each area or street in the city and each hsiang in the countryside. ${ }^{133}$ Committee members were to be elected by "representatives of residents," and had to be "politically upright" persons with "close links with the masses" and "enthusiastic" about mediation work. ${ }^{134}$ They were enjoined to carry out mediation "according to policy and law," and to mediate cases only when the parties voluntarily agreed to mediation. ${ }^{136}$ They were ordered not to prevent parties from going to the courts if they wished, ${ }^{136}$ and were prohibited from accepting bribes or showing favoritism, punishing or detaining parties, and "oppressing or retaliating against parties." of production, listen to the views of the parties concerned, conduct penetrating investigation and study, fully acquaint themselves with circumstances of the case and adopt a polite and patient attitude and method

128 2nd All-China Judiciary Conference Convened in Peking, NCNA Peking, May 12, 1953, English translation in SCMP No. 573, at 15 (1953).

129 Id.

130 Provisional Rules Governing Organization of People's Mediation Committees, Feb. 25, 1954, CHUNG-YANG JEN-MTN CHENG-FU FA-IING HUI-PIEN [COMPENDTUM OF THE LAWS aNd Regulations of time Centrat People's Governarent hereinafter cited as FLHP] 47, English translation in SCMP No. 784, at 11 (1954).

131 Id., art. 1.

$132 I d .$, art. 3.

133 Id., art 4. The hsiang, "administrative village," is a rural administrative unit composed of several natural villages.

134 Id., art. 5.

135 Id., art. 6.

$136 \mathrm{Id}$.

137 Id., art. 7. 
of persuasion."138 Cases were to be registered, and documents embodying the parties" agreement were to be issued to the parties "when necessary."139

The official Peking People's Daily hailed the new legislation and the role of the mediation committees in aiding socialist construction. "Unity is strength," its editorial began, "unity is the strength to impel forward the masses of the people in production and construction." ${ }^{2140}$ The editorial stated that litigation had increased in China; because of the need to handle the increased volume of disputes without interfering with production, an organizational means had to be fashioned to deal efficaciously with disputes and to free basic-level cadres and the courts for more important tasks such as deciding cases of alleged interference with economic construction. The editorial echoed the regulations by condemning corrupt and coercive practices and ended by reiterating the call for unity for the sake of production. ${ }^{141}$

Mediation committees liave continued their work in residential areas since their establishment in 1954, occasionally undergoing apparently temporary changes. In some places they were merged for a time with the security defense committees. Also, during the first years of the rural communes, 1958-1960, mediation committees in some areas were transformed into "adjustment [t'iao-ch'u] committees" with an even more explicit mobilizational role than their predecessors. The "adjustment committees" not only mediated disputes, but organized meetings for adopting "patriotic pacts" (ai-kuo kung-yïeh) in which all present vowed to obey Cliairman Mao, the Communist Party, labor discipline, policies, law, and Communist morality; to protect public property and public order; to maintain good relations with family and friends; and to watch for "bad men" and maintain public health. ${ }^{142}$ However, "adjustment committees" do not seem to have replaced mediation committees;

$138 I d .$, art. 8.

$1397 d$.

${ }^{140}$ Do Well People's Mediation Work, Strengthen the Unity of the People and Facilitate Production and Construction, People's Daily, Mar. 23, 1954, English translation in SCMP No. 784, at 12 (1954).

141 On the same day, an editorial in the Peking Kuang-ming Daily also harked back to the experience with inediation committees in the Communist-controlled areas before hberation; Correctly Develop People's Mediation Work, Short Comment, Kuang-ming Daily (Peking), Mar. 23, 1954. Both editorials stated that nation-wide efforts to form mediation committees were needed because in some places the "mediation small groups" had been disbanded.

142 See Teng Chih-lisiu, People's Adjustment Work in Anhui During the Leap Forward, Polttical-Legat Researce No. 2, at 33 (1960); Chiang Shih-min, Su Mei-feng, Li Wen-ch'eng, Le Ching-t'ang, Correctly Handle Disputes within the People, PortricaI-LEgat ResearcH, No. 4, at 28, 29-30 (1959), describing an assortment of devices that can be used to "educate" persons, including "large wall posters," "large discussions," "democratic debates," "family meetings," "persuasion" by friends and families, negotiations, and mediation. 
they have been little mentioned for the last five or six years, while mediation committees continue to receive praise for their dispute settlement activities $^{143}$ and for the valuable support they give to production. ${ }^{144}$

(b) Mediational style.-Mediation committees were developed as mobilizational instruments to link dispute settlement with Communist attempts at reordering society and to conform dispute settlement policies to the needs of socialist construction. The intended role of mediation committees is made more explicit by published reports about work of model mediators held up to readers as worthy of emulation. These stories suggest the qualities which mediators are supposed to possess and the values they are supposed to foster and reinforce. However, to determine low mediators actually conduct their activities, the author found it necessary to synthesize with these reports information obtained from interviews with Chinese emigrés.

Mediator Aunty Wu, described briefly at the beginning of this Article, ${ }^{145}$ illustrates some of the ideal mediator's most desirable attributes. She was praised for hurrying to investigate a disturbance she heard while walking along a street. Her "links with the masses" were com-

143 However, doubts were entertained briefly about their value. In 1956, a debate was conducted on whether the committees should be retained or disbanded. The committees had actually been abolished in some places, and opposition to their continuation elsewhere was strongly voiced. Those in favor of doing away with the committees argued that many disputes were not settled by inediation cominittees at all, but by cadres or residents committees, partly because "dual leadership" of local administrative units and courts had caused diffusion of responsibility and neglect of dispute settlement. Also, it was argued that with increased rural collectivization, some disputes that had been regarded as involving different groups of peasants bad now become disputes within single entities-the new cooperatives-and therefore amenable to settlement entirely within the cooperative. Moreover, it was argued that disputants often preferred to ask a cadre or some other person known to them to settle a dispute rather than the inediation committee. No one argued for increasing judicial responsibility for dispute settlement, although several judges argued that mediation was specialized work that should be guided by the courts.

In opposition, some cadres argued that so many disputes were unrelated to production that settlement of such disputes would interfere with cadres' duties to supervise production. They also argued generally that responsibilities for supervising settlement of disputes would take up too much of their time. Their views prevailed, and the mediation committees have continued to exist. Should Mediation Conmiltees in the Cities and Countryside Continue to Exist? Kuang-ining Daily (Peking), July 16, 1956; Is It Necessary for Us to Retain People's Mediation Committees? Id., Sept. 2, 1956, English transiation in SCMP No. 1391, at 7 (1956).

144 In late 1964 an article in the principal Chinese legal periodical, Yeh Ku-lin, Fully Develop the Role of People's Mediation Work in Serving the Construction of Socialism, PolitiCAC-LEgAi RESEARCE No. 4, at 12 (1964), English transiation in SCMM No. 461, at 1 (1965), discussed the purposes of mediation and the expectations held for it by the Party. The article, besides extolling mediation's promptness and its beneficial effects on the people's unity and political consciousness, characterized it as "the first line of defense in legal work." The article emphasized the political goals of mediation, its usefulness as an auxiliary to other political measures, and its role in managing rural communes.

145 See text accompanying, note 1 supra. 
mendable, because before investigating directly, she talked to neighbors and later involved them in resolving the case of the unrepentant childbeater. Her persistence was also praiseworthy, as were her close ties with cadres. ${ }^{146}$ Whenever she encountered a case that was difficult to settle, she would consult the head of the local street business office and the local people's court; after a difficult case was settled she would report again, asking for cadres' opinions. By maintaining these close relations with cadres, she was able not only to settle disputes but to "raise her own political consciousness."

Aunty $\mathrm{Wu}$ is not an isolated example. Other mediators have been praised for rushing to the spot where a dispute arose, ${ }^{147}$ for cooperating with cadres and other activists, ${ }^{148}$ for maintaining close relations with the masses, and for persisting in their efforts to resolve disputes. ${ }^{149} \mathrm{An}$ other exemplar of these traits is one Li Erh-ma, a lady mediator like Aunty $\mathrm{Wu}^{150}$

One day, Li Erh-ma, chairman of a mediation committee in Nanking was at home, when another mediation committee member came running to tell her that three fights had occurred within the last two days in the home of Wang Ying and that she did not understand the cause of the trouble. The next day, after breakfast, Mrs. Li went to the Wang family's neighbors. She learned from them that Wang and his wife were living with Wang's mother and younger sister, that Wang's

146 Model Mediator Aunty Wu, Kuang-ming Daily (Peking), Oct. 14, 1955.

${ }^{147}$ See, e.g., Mediation Committee Member Li Jui-neng of Yu-hsiu, New China Daily (Chungking), June 11, 1953: "He is concerned about the masses' suffering, and as soon as he hears that the masses have disputes or that disputes are starting up, he immediately rushes (chu-tung kan-ch'ii) to settle them." See also, How I carried Out Mediation Work, Shensi Daily, Mar. 25, 1957, in which the author-mediator tells of a dispute between spouses over whether to join an agricultural cooperative. "After [he] heard about this," wrote the author, he rushed to the spot to convince a conservative mother-in-law that it was an ideological error to try to restrain her daughter from joining a rural cooperative with her husband.

148 Of one model committee, it was reported: "Primary in the work of [the committee] was to be able to have closer relations with the basic-level street organizations. . . ." So close were its relations with other organizations that in a divorce case, the committee consulted with the local Women's Association, How the Mediation Committee of Ho-pei yoi in Hsi-fang District Carried out Its Work, Tsingtao Daily, Apr. 8, 1955. For another typical description, see $A$ Ball of Thread with One Thousand Knots, Mediation Committee Unties Them; City Mediation Committee Performs an Important Function in Handling Cases, Canton Daily, July 18, 1957, reporting that "after the mediation committee of P'eng-lai Street learned [of a dispute between neighbors over a minor debt] it forthwith met with the Women's Association to carry out criticisin and education of the two parties."

149 One mediation committee was so zealous that when it heard of a domestic quarrel it immediately rushed out to mediate the dispute-at midnight. Ch'en Kuan-hua \& Chiang Cheng-chieh, How Mediation Work Was Carried Out in Chi-shan Hsiang of Kunming, New China Daily (Chungking), June 11, 1953.

$150 M$ ediation Chairman, NCNA news release (in Chinese), Nov. 24, 1961. The author has directly translated only the quoted material and has summarized the rest. 
wife wanted her sister-in-law to do more around the house, and that Wang's mother and sister resented the wife's demands. Mrs. Li then went next door to the Wang house, where she found only Wang's mother, who was taking care of Wang's hittle children. Wang's mother admitted that she did not get along with her daughter-in-law. Mrs. Ii said: "You and I are ahike. I've been a mother-in-law and in the past $I$, too, had a little of the old ideology, and always felt differently about my daughter and daughter-in-law. Now society is different, our ideology has changed a little, and we must treat daugliter and daughterin-law alike." Just then the daughter-in-law came home, and while Mrs. Li lielped her prepare vegetables, she congratulated her on having a mother-in-law who helped, too. "They only come to eat and scold all day, and don't do anything," replied the wife. Mrs. Li explained that children were parent's responsibilities, and that younger and older generations owed each other respect. Later, Mr. Wang came lome, and Mrs. Li lielped the family hold a "family unity and reconciliation meeting" in which each member of the family discussed his or lier errors.

Days later, Mrs. Li was still concerned about the Wang family, and she became even more concerned when she met Mr. Wang on the street, asked him how all the Wangs were getting along, and received only a very liesitant reply that things were all right. Slie returned to the Wang house, and helped the Wangs have another meeting to talk until there were no more differing opinions. Ten days later, she returned again, and the Wangs said: "Li Erh-ma is so concerned about unity and reconciliation in our louse! This is really extraordinary devotion. From now on, we won't fight."

As one would expect, mediators are particularly commended when they combine dispute settlement with propaganda activities. It was said of one model mediator that she "was not only an activist mediator, but a very good propagandist. Through mediating disputes, or using large or small meetings, she correctly propagandizes national policies and laws to the masses .... ."151

Model mediators cannot be dismissed as stage people, however artificial their reported words and deeds may seem to foreign readers skeptical of propaganda. Although they represent ideals, they also represent expectations and desires that have often been substantially realized by a leadership that, at least in the past, has known well the people it leads. Emigré interviews clearly confirm that mediation committees' styles and roles are highly pohticized.

There is considerable evidence that many mediators are activists. Often they are participants in Party-sponsored work with youth or women; indeed, their enthusiasm and commitment in other work may have led to their selection as mediators. A high proportion of urban 
mediation committee members are also small group leaders or members of residents committees. Mediators in cities are frequently unemployed housewives active in women's work with much time on their hands to stay at home-or pry into their neighbors' affairs.

One should not conclude that because many mediators are activists, the political quality of mediation is pervasive. "Activism" is highly relative to near or total passivity, if not discontent with and even opposition to the Communist Party. It is obvious that the Party encounters difficulties in recruiting activists and in maintaining a high level of commitment. It is certainly sometimes true that "given the relatively low level of political consciousness among urban housewives, willingness to serve is in itself sufficient 'activism' to receive Party acceptance."152

Thus, it is not necessarily true that because a mediator is an activist, he will exhort disputants to carry out Party policies. Published sources and emigré accounts agree that many urban mediators are poorly educated and often barely hiterate. While the pubhished sources stress that poorly educated mediators suffer from no real handicap as long as they are politically motivated, emigrés indicate that such mediators are ineffective propagandists who, moreover, lack authority and respect in their neighborhoods, particularly among younger and better educated neighbors.

Although a meagre commitment may suffice, faute de mieux, as activism, and although many mediators may be inarticulate and unheeded, many talkative, earnest, and dismayingly patient mediators like Aunty $\mathrm{Wu}$ engage in verbose mediational activities throughout China. Moreover, mediators are ubiquitous. Not only does the Party expect mediators to know well the people among whom they dwell, but sometimes it is impossible for mediators not to be exceptionally well-informed about their neighbors. Several former residents of Canton, when asked in Hong Kong interviews how outside mediators could learn about disputes, replied that it was almost inevitable under crowded conditions for small group leaders or other activists to hear of a dispute; very often, indeed, activists actually hear the dispute when it erupts and try to settle it immediately. One person interviewed recalled an incident in which one of his neighbors accused another of stealing a chicken. The accused thief indignantly denied the charge, but his guilt was exposed when their common small group leader recalled seeing the suspect eating chicken the day after the theft.

162 J.R. TowNSEND, supra note 66 , at 164. Further illustrating that activism may be very weak indeed are the frequent emigrés who have told researchers that they greatly improved their chances of obtaining approval of their apphications to leave China for Hong Kong by feigning activism for an extended period of time before applying for permission to leave. 
It is also clear from emigré recollections that mediators are closely linked with cadres. The policeman, charged with knowing well persons and events on his "beat," circulates on the streets of that area and frequently stops for a word with street activists. But the policeman is not the only cadre who is readily accessible. When an activist such as a small group leader, security defense committee member, or mediation committee member attempts unsuccessfully to settle a dispute, he may report it to the police, to the residents committee, or to the street business office and ask them to send someone to mediate the dispute. Even if only one orgamization is notified, representatives of several may come. So, if a small group leader asks a mediation committee member to come to a neighborlood, the mediator who comes may be accompanied by a policeman, a cadre, an activist member of a residents committee, or several of these people. An illustrative dispute is the following:

In a large Southern city, a woman lived with her grown son in several rooms, renting one to a lodger. The family had relatives in Hong Kong who occasionally sent food packages which included cooking oil. The son discovered that some oil they received was missing, and accused the lodger of taking it. The two men began to argue violently after the son called the lodger a thief, and the lodger replied by calling his accuser a "bourgeois." In a rage, the two men set about destroying each other's possessions.

Their small group leader heard the commotion caused by the dispute, and came runming to see what was the matter. She tried to calm the two, and succeeded in persuading them not to fight any more. She did not, however, solve the issue of the alleged theft, and the same evening the argument broke out again.

This time, the small group leader went directly to the street business office, and returned with a policeman and the chairman of the street mediation committee, who "invited" them to come to the street business office. There, the activists and the pohiceman heard the two parties, who repeated what they had already told the small group leader. When the lodger again called the other a "bourgeois," the pohiceman somewhat sternly replied that he knew the family was receiving packages from Hong Kong, but that no violation of law nor policy was involved, and besides, it was wrong to go around calling people "bourgeois." He further lectured to the lodger on the impropriety of taking other peoples' belongings, and of scolding and quarreling with people. The mediation committee member lectured to both disputants on the unseemliness of their conduct; both men were comrades, he told them, and must also obey the law and not figlit. The session at the street business office lasted for about a half-hour, after which the two men returned home together.

This and other similar emigre accounts indicate that in crowded Chinese cities, the net of "basic-level" organization is tightly meshed and that 
disturbances and disputes are given close attention by the activists, including the mediators, and the cadres with whom they maintain close contact. Although mediation is formally differentiated from other activist responsibilities, activists other than mediation committee members and policemen frequently become involved in settling disputes. In fact, emigrés frequently do not distinguish between mediators and other persons likely to handle disputes; their accounts suggest that a small group leader, a security defense committee member, a residents committee member, or a policeman is as likely to handle a dispute as a mediator. ${ }^{153}$

Since mediators are activists, mediation is ideally conducted in the activist style-persistent and mobilizational. The standards used by urban residential mediators in resolving disputes reflect the activism of at least some mediators, and the involvement of cadres, especially policemen, in efforts to settle disputes. These standards, however, are most meaningfully understood in conjunction with mediation in other contexts. As already indicated, mediation of disputes is the universally favored mode of dispute resolution, whether the forum is street, courtroom, or factory. Mediation in courtrooms and factories, however, differs somewhat from residential mediation. Analysis of the mediators' standards is postponed, therefore, until after an examination of these other types of mediation.

\section{B. Judicial Mediation}

In judicial as well as extrajudicial dispute resolution, a standard Communist slogan stresses that "mediation is primary, and adjudication is secondary." If mediation by neighborhood mediators or cadres is unsatisfactory, one or both parties may request the local people's court to settle the matter. Extrajudicial mediation is not a formal precondition to submitting a dispute to the courts; indeed, attempts by cadres and "activists" to coerce settlement or otherwise deny parties recourse to courts have been repeatedly criticized. ${ }^{154}$ But once the issue is brought to the courts, mediation and not adjudication will most likely follow.

\section{The Politicization of Judicial Mediation}

The emphasis on mediation in the courtroom was clearly increased in the "legal reform" movement of 1952-1953. Judges not only practiced mediation in their courts but encouraged and supervised mediation outside the courtroom. A graduate of one of China's major law schools re-

153 The unpublished interviews of Professor Victor $\mathrm{Li}$ make this clear. See note 2, supra.

154 See, e.g., Yeh Ku-lin, supra note 144, at 16, SCMM No. 461, at 8. 
called participating in such judicially-directed mediation during his last year of law school in 1952:

The local district court would from time to time send the files in a batch of civil and minor criminal cases and a team of judges to the law school, where under supervision the students acted as judges and dealt with the cases or "practical exercises." Before each such occasion, a cadre from the court would come to the school and lecture the students on the type of cases which would be brought to the school next, and on the laws and policies applicable to them. For example, he would announce that divorce disputes would comprise the next group of cases, and he would lecture on the new Marriage Law. Thereafter, an announcement would be posted outside the law school, stating the date on which particular classes of cases, such as those involving the Marriage Law, would be decided.

On the scheduled day, a cadre would again come from the court, and lecture on the applicable laws and policy. In marital disputes, for instance, he urged the students to be attentive to the bad influences of the old society, the oppression of women before the Revolution, the changes wrought by the Revolution, the equality of women and men, and the necessity to protect women. After the lecture, the students were divided into pairs and went to a large room where cases were to be heard; each pair was seated behind desks arranged in a rectangle parallel to the sides of the room. The litigants, some witnesses, spectators, and other law students crowded around the walls of the room.

The students in each pair alternated as judge and recording secretary. The "judge" would read the file in a case, call the parties, and they would step forward from the side of the room and stand before the desk, "like going to see a doctor," as this participant recalls. The judge would question the parties in turn, while other litigants, students and spectators stood and listened. The students had been told to mediate disputes whenever possible, consistent with the policy of "mediation as primary, adjudication as secondary," and, if the parties did not consent to a proposed solution, to send them away rather than adjudicate the dispute. The students questioned the witnesses who had been brought along, if any. After the issues were clear, the students would try to mediate the dispute in an effort to "educate the parties and the spectators."

One newly married couple requested a divorce. The husband worked in a factory by day, while the wife was employed at night. The husband wanted to have sexual relations with his wife in the evenings. She frequently refused, because she had to go to work and the husband, enraged, often beat her. The student to whom this dispute was submitted talked to the couple about women's rights, the valuable service the wife was performing to aid "national construction," and the couple's need for the wife's income. The husband protested that none of these considerations were relevant to his problem. The student told him that he would not grant a divorce, and that the couple themselves must think of a way (hsiang pan-fa) to settle it themselves. The parties went away. 
The foregoing account, like published reports of judicial mediation at this time, strikingly emphasizes resolving disputes in terms of highly generalized pohicies and educating parties and spectators, an approach corresponding with that followed in extrajudicial mediation. The student judge's apparently inconclusive handling of the marital dispute described above undoubtedly resulted from the highly politicized quality of mediation. The policies the law students were expected to apply in handling disputes had been summarized in abstract and generalized terms, which were in turn repeated to the parties. The parties were not formally coerced into accepting a decision that imposed on them an unacceptable situation, but the judge's words and behavior made clear to them that the people's government, speaking through its court, would not permit disruption of production.

Additional evidence of the courts' stress on political policy in mediation is provided not only by published discussion, but by recollections of emigrés who were parties to disputes handled by the courts.

So, for instance, in a large Chinese city, a house owner of "bourgeois" class origin rented several rooms to a high-ranking cadre who thereafter failed to pay his rent for a long period of time. In 1956, the landlord overcame his reluctance, as a person of "bad" class origin, to become involved in a dispute with a cadre, and went to the street business office, where the dispute was mediated. Landlord and tenant agreed that the rent was owed and unpaid, but the tenant stated that he had a large family to support, and very little money. He agreed, however, to pay a fraction of the rent monthly thereafter, and to think of a way (hsiang pan-fa) to pay the balance. Three months elapsed without any payment by the tenant; the landlord returned to the street business office, but the mediator could not resolve the dispute.

The landlord then went to the local people's court and asked to see a judge, whom he hold of the dispute. Thereafter, landlord and tenant were summoned to appear together. After each stated his position, the judge noted the landlord's "bourgeois" origin and the tenant's "worker" origin and cadre status. He stated that it was the of duty of "bourgeois" to help "worker," and that therefore it would be incorrect for the landlord to take money from his tenant. He added that if the tenant could pay at a later date, he would be ordered to do so, but since he could not pay at that time, he could not be ordered to pay anything at all.

The mediational style of the courts is further illustrated by divorce disputes, which comprise the bulk of civil cases handled by the courts. ${ }^{155}$ Under the Marriage Law, mediation of divorce disputes is mandatory when one spouse insists on, but the other opposes, divorce. ${ }^{156}$ Extrajudi-

155 See, e.g., Work Report of Higher People's Court of Kirin, Kirin Daily, July 22, 1956, English translation in SCMP No. 1874, at 18 (1958).

156 The Marriage Law of the People's Republic of China, art. 17, 1949-1950 FLHP 32, 
cial mediation, often highly intense, precedes judicial disposition of divorce cases, but the courts may also engage in intensive efforts to mediate. ${ }^{157}$ Visitors who have observed divorce cases have commented on courts' efforts to protect the position and rights of women who were, in the cases observed, often of lower class origin than their husbands, not as well educated, and sometimes victims of mistreatment by husbands or husbands' families with "feudal" or "reactionary" ideas.

So, in one divorce case in which the wife complained of frequent beatings by her husband and his family, the judge attempted to reconcile the couple and blamed much of their trouble on the father-in-law's "oldfashioned mentality." Even when the wife refused to be reconciled, the judge refused to grant a divorce unless the couple first attempted to he apart from the husband's family. ${ }^{158}$ In another case, a "bourgeois," welleducated husband and the wife he had mistreated were reconciled after the husband was brought to admit his "bourgeois attitude" and promise to correct his "erroneous attitudes." "159

\section{The Differences between Judicial and Extrajudicial Mediation}

Accounts of divorce disputes suggest that while courts appear to settle disputes in the same manner as mediation committees, their style of mediation may be more concentrated and perhaps more intimidating to the parties. While the courts may prefer mediation to adjudication, parties cannot help being aware that courts wield more power than the neighborhood mediators. Moreover, it can be conjectured that the judges,

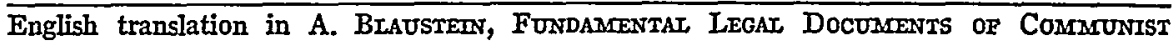
ChINA 266 (1962).

157 A graduate of the Peking Political-Legal School interviewed in Hong Kong, after volunteering the idea that courts were not extensively used in China to settle disputes, was asked what means were employed.

He described a typical divorce case: A spouse who wanted a divorce would not go to a court, but to the mediation committee or residents' committee in the couple's neighborhood. The mediator would call on the couple's fanily, neighbors and fellow workers to assist in resolving the dispute. If, after several unsuccessful attempts to end the matter and effect a reconciliation, the complaining spouse still insisted on a divorce, he or she could go to the court, but a judge, before deciding the case, would speak first with the parties, their families, friends, neighbors and fellow workers. Frequently, too, after the complaining spouse's place of work was notified, a meeting would be called there to persuade complainant to desist. Only after all of these devices were exhausted would the court decide the case.

In cases in which divorce was sought by a spouse of "bad" class origin with an education better than the other spouse of "better" (i.e. lower) class origin, the complaining spouse might very well be criticized for looking down on his less educated partner and exhibiting "bourgeois ideology."

158 Chome, Two Trials in the People's Republic of China, I. IN THE SERviCE of PEACE: R. OF CONTEMP. L., June 1956, at 163.

159 F. GReENe, Awarented Chena 199-209 (1961). See also Woodsworth, Family Law and Resolution of Domestic Disputes in the People's Republic of China, 13 McGrI L.J. 169 (1967). 
full-time cadres whose job is dispute settlement, may be better and more systematically instructed $\mathrm{m}$ policies than the street activists. The apparent difference between judicial and extrajudicial mediation in urban neighborhoods suggests that, although mediation is discussed in Communist Chinese sources as if it were a single, well-defined method of resolving disputes, it may vary significantly with the type of mediator. Even stronger evidence of such variation may be obtained from a study of mediation in yet a third type of forum, the factory or other place of work.

\section{Mediation within Organizations and Rural Communes}

"Rely on the organization, believe in the organization." "180 One of the most important questions that can be asked about a person in China is, "To what organization does lie belong?" A person's "organization" is his place of employment, or, if he is a student, his school. An organization may be a government ministry or bureau, a factory, railroad, department store or other economic enterprise, a university, or a school. Most Communist Party members who are not full-time employees of the Party also belong to organizations in their capacities as cadres or workers, although they owe their primary commitment and allegiance to the Party. ${ }^{161}$

For all Chinese who belong to one, an organization is much more than a place of work or study. For many, who bive in quarters operated and managed by their place of employment, it is a home. ${ }^{162}$ Moreover, organizations have mobilizational purposes. They are arenas for disseminating values consistent with national goals, ${ }^{163}$ and are supposed to provide meaningful experience in collective activities and in the work of constructing a strong, socialist China. The political and social roles

100 Chinese Communist slogan.

101 For Party members who are also full time employees of the Party at Party Committee offices, Party and organization are, of course, synonymous.

162 For example, numerous cadres in government bureaus, policemen, workers, teachers, and students live at the location and under the jurisdiction of, their organizations.

103 See, e.g., Tientsin No. 4 State Cotton Mill Guides Spare-Time Activities of Workers in an Earnest Manner and Enables Them to Lead a Rich and Colorful "After-Work" Life, People's Daily (Peking), Jan. 19, 1961, English translation im SCMP No. 2426, at 13 (1961); Make the Collective Dormitory Work a Success, Peking Daily, May 13, 1964: "Dormitories are places for rest and sleep but are not only places for rest and sleep. Having labored, worked and studied, people will naturally talk about questions of general interest in the dormitories. Personal likings and troubles will naturally leak out in the dormitories. These activities and manifestatious of spare-time life or extracurricular life often reflect the thought deep in one's mind. For this reason, if we are to give every care to the healthy growth of young people, we must attach great importance to dormitory work, talk with those living in the dormitories about various questions from time to time, guide them to take interest in the socialist revolution and socialist construction, and correctly solve various ideological and practical problems." 
of organizations, including, of course, dispute settlement, greatly affect the lives of their members.

\section{The Organizational Context}

When the first formal regulations for nationwide organization of mediation committees were promulgated in 1954, mediation committees were also establislred in some economic enterprises-particularly in their residential quarters. ${ }^{104}$ During the past ten years, however, the Chinese press has printed very little concerning mediation committees in enterprises, although it has publicized and praised mediation committees in residential areas. Furthermore, emigrés who have spent time in economic enterprises or educational institutions do not associate mediation committees with such organizations.

Despite the absence or inactivity of mediation committees in organizations, mediation is used to resolve the many disputes among organization members and between members and nonmembers. Unlike mediation in residential units, mediation in organizations is not formally differentiated from other tasks performed by persons with official authority.

The liypothetical $\mathrm{Mr}$. Lu, whose neighborhood was used above to illustrate the organizational context of mediation in residential areas, will encounter in his work environment many persons with authority. The control apparatus existing at the neighborloood level permeates Mr. Lu's factory, office, or school. In a large factory or bureau for instance, a Party hierarclry extends downward from a Party secretary and Party committee to Party branches in workshops or offices and Party small groups at the lowest level. ${ }^{165}$ All workers, whether or not Party members, are organized into small groups with the same indoctrination functions as the residents small groups.

Every organization contains units for "security" and "personnel." In smaller organizations they are often merged; in large organizations such as major government offices, important factories, and universities, the personnel and security units are not only separate but large. The cadres who work in these sections are expected to be politically reliable - Party or League members, or activists. The personnel sections have custody over the dossiers of all persons in the organization. Job assignments and salaries turn largely on political considerations weighed by Party cadres. Because the Party is obviously concerned with knowledge

164 See, e.g., Correctly Develop People's Mediation Work, Short Comment, Kuang-ming Daily (Peking), Mar. 22, 1954; This City Holds Meeting of Representatives of Advanced Mediation Workers; 10 Advanced Units and 74 Advanced Workers Reap the Benefits of the Meeting, Tsingtao Daily, April 24, 1956 (dormitory dependents' committee).

165 For a detailed study of Party control in a Peking ministry, see A.D. BARNETr, supra note 65 , at $18-37$. 
about cadres and workers, personnel sections are closely linked with the organization's Party committee; emigrés often regard these sections as mere extensions of the Party committee. ${ }^{166}$ Security sections are responsible for investigating and controlling crime, sabotage, accidents, and disturbances within the physical confines of the organization. Security sections, functioning much like police stations in residential areas, report to and receive directions from local police subbureaus.

An assortment of people supervise and direct the work of the organization's component units. Supervisors such as section chiefs in offices and workshop foremen in factories work closely with the people they supervise. Moreover, units of such national groups as the Women's Association and the Young Communist League conduct their mobilizational work within organizations. The labor union is an important adjunct of the Party in economic enterprises. ${ }^{167}$ And, of course, small group leaders are the lowest-level representatives of the control apparatus. In short, if $\mathrm{Mr}$. Lu works in a factory, his contact with the organizational apparatus can be represented as follows: ${ }^{168}$

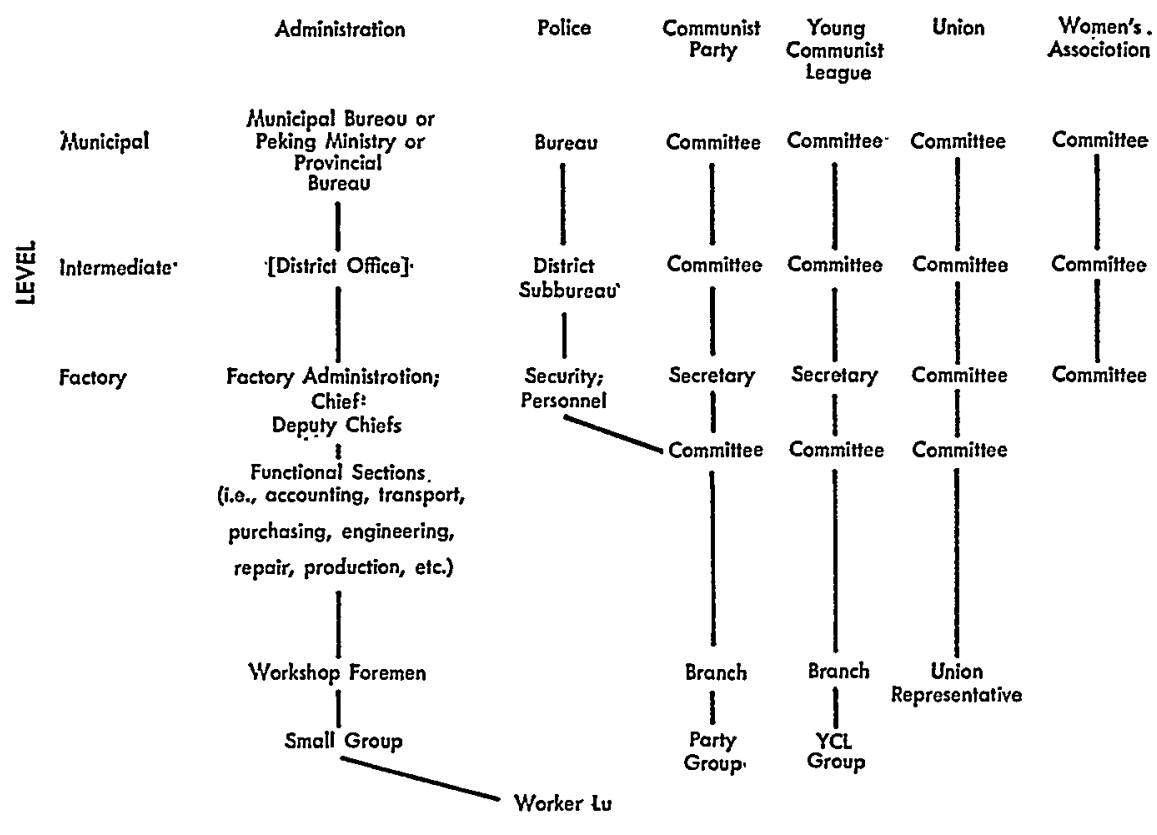

$166 \mathrm{Cf}$. id. at 20 generalizing from study of a Chinese ministry: "In the government in China virtually all personnel units are staffed entirely by Party men, and in effect they act as extensions into the government structure of the Party's organization departments, which have the power of ultimate decision about government personnel, including both non-Party and Party cadres."

${ }_{167}$ See, e.g., Communist Party Comnittee of May 3 Factory, How does the Party Committee Exercise Stronger Leadership Over the Trade Unions, Worker's Daily (Peking), Sept. 19, 1961, English translation in SCMP No. 2602, at 4 (1961); An Important Matter, 


\section{The Mediators and the Process of Mediation}

(a) Mediation in Urban Organizations.-In the small world of the organization, which is partially closed to the rest of society, the persons identified above must deal with social conflict ranging from petty disputes to major sabotage. If cadres or workers steal, habitually come late to work, work poorly, are involved in accidents, fight, or argue with each other, such incidents are handled, at least initially, by supervisors, personnel or security cadres, administrative cadres, and small group chiefs. Because dispute resolution is not differentiated from other aspects of organizational administration and labor disciphne, it is difficult to match types of disputes with the persons who resolve them. However, some tentative generalizations can be made.

If two cadres or workers employed in the same office or production unit become involved in a dispute, their supervisor is likely to become involved in resolving it. If he fails to end the quarrel or if a dispute arises between two cadres or workers from different units of the same organization, the organization's personnel section may become involved. If one or both of the disputants are Party or League members, their branch secretaries may also become involved. ${ }^{109}$

Disputes may be settled within the organization regardless of whether

Worker's Daily, Aug. 29, 1961, English translation in SCMP No. 3297, at 8, 10 (1961) ("The trade union is a bridge linking the Party and the masses.") Unions not only engage in propaganda work and efforts to mobilize workers to increase production or fulfill economic plans, but also administer educational, cultural, and welfare programs including the labor insurance scheme of compensation for injuries. See, e.g., Labour Insurance Regulations of the People's Republic of China, arts. 21, 25-31, Feb. 23, 1951, FLHPP 397, English translation in Important Labour Laws and Regulations of the People's Republic of China (1961). After nationalization of China's industry was completed in 1957, the trade unions lost to Party committees some of the supervisory and administrative functions they had performed in privately-owned enterprises. Their mobilization role has continued to exist.

108 The diagram is an oversimplified representation of the lines of authority within a large factory and from that factory upward to Party and government organizations. It should be noted that the level of authority between the citywide administration and the factory itself is ambiguously denominated as "intermediate." In some cases, units within the factory would be linked to a territorial superior, for example, at the district level. Thus, factory security sections, especially in small factories, would be responsible to district police subbureaus. In some cases, however, units within the factory would be linked with a functional superior such as an organization at the municipal level (but subordinate to citywide Party and government) which deals with enterprises or activities with similar functions. So, for instance, the Party committee in a large textile factory would be responsible to a Party committee for the textile industry in that city.

109 Party and League members are supposed to be models and leaders for the rest of the society and are therefore subjected to considerable discipline; their personal problems are often matters of great concern for Party and League branch secretaries. See, e.g., Work Committee of Young Peasants Departınent, Central Committee, Young Communist League, Report on Investigation of the [Young Communist League Branch] of Hsiaohainten Prodaction Brigade of Ch'enghsi Commune Linhai Hsien, Chekiang Province, China Youth 
they arise from the duties of the disputants or the activities of the organization. Thus, arguments over unpaid debts or other personal matters may arise within the organization and be resolved by its mediators. ${ }^{170}$ For instance, work supervisors may attempt to resolve disputes arising out of rivalry between nuale subordinates over a woman. Furthermore, supervisory personnel may settle disputes between organization members and outsiders, who can, and sometimes do, complain to the organizations about such disputes. For instance, landlords not belonging to the organization may complain that a tenant employed by the organization has not paid his rent. Personnel sections and work supervisors investigate such complaints and may order noonthly garnishments of a portion of the tenant's salary.

Labor union cadres also handle many disputes. ${ }^{171}$ Cadres in charge of union welfare programs are often asked by workers or workers' dependents to settle disputes over debts, petty thefts or damage to property, noise in residential quarters, and children's fights. In particular, union cadres apparently handle nany marital disputes. When workers want divorces, unions often conduct investigations like those of mediators in residential areas, sending persons to talk with the parties, friends, and neighbors, and holding meetings of fellow members to "assist" a comrade seeking a divorce to desist. As in disputes arising wholly within residential units, unsuccessful attempts to mediate may be followed by recourse to the courts.

Organizations' investigations are often coordinated with those of neighborhood mediators; therefore, both neighborhood and organization mediators may appear before the court. Since the court would probably try to mediate the dispute, judicial participation in the case nuay involve further factfinding and investigation in conjunction with a variety of organizations. An illustrative case is the following:

In 1964, a worker employed on a cargo lighter in the Canton harbor discovered that his wife had been having extramarital relations with another man. He arranged for several of his fellow workers, one of whom was the labor union representative on the lighter, to follow

Newspaper, May 21, 1961, English translation in SCMP No. 2488, at 4, 8 (1961): "League Member Wang Mei-hua had a quarrel with her husband. The people who recommended her to join the League and the League branch cadres successively persuaded her for six or seven times to seek reconciliation with her husband, and the result was that their differences were patched up."

170 See, e.g., Lo Hua-han, Go to Worker's Dormitories to [do Mass] Work, Worker's Daily (Peking), Mar. 11, 1964, English translation in SCMP No. 3192, at 10 (1964) (Party member living in dormitories improves workers' ideology, settles their disputes).

171 This is one of the ways in which unions assist Party and managers in factory administration. 
the wife to a rendezvous with her lover. They followed her to a hotel, and noted that she entered, and remained for several hours before coming out again. Thereafter, he notified his neighborhood mediation committee that he wanted a divorce. The mediators held three sessions to try to reconcile the couple.

At these mediation sessions, the wife admitted that she had male friends, but denied that she had had sexual relations with them. She complained that she could not get along with her husband's mother, who hved with the couple, and that because she was entitled to her freedom she had no obhgation to remain at home. The husband was enraged at his wife's unfaithfulness, her disrespect for his mother, and her neglect of their only child; he insisted on a divorce. The spouses remained adamant, and no reconciliation could be effected. After the third mediation session, the husband wrote a letter to the district people's court describing his wife's misconduct, and requested a divorce and pumishment of the wife's lover. His fellow workers who had followed the wife to her alleged rendezvous also signed the letter.

The court held a hearing at which a judge and several jurors ${ }^{172}$ heard the couple, the fellow workers who testified to having followed the wife and seen her enter the hotel, and the mediation committee's chairman, who stated his opinion that the evidence of adultery was insufficient. The judge agreed with the mediator, attempted unsuccessfully to reconcile the couple, and then adjourned the court.

After the first session of the court, the Party secretary of the husband's work unit wrote to the alleged lover's Party secretary, telling him of the case and asking him to investigate the alleged lover's record and conduct. The response came back that it was "possible" but not proven that the alleged lover had had rendezvous with a number of married women. The husband's Party secretary also wrote to the Party secretary of the factory which employed his wife, urging him to "educate" her. Thereafter, several meetings were held of the wife's fellow workers, who attempted to convince her of her errors, especially in neglecting her child, but she was unrelenting. A second session of the court was then announced.

When the court reconvened, the judge announced that he had sent jurors to the alleged lover's place of employment, where thorough investigation indicated that he had had a number of affairs with married women, and that as a result of his misconduct, he had been transferred. In addition, the jurors had spoken to the parties' neighbors and fellow workers, and the Party secretary of each spouse's place of employment. The judge reviewed the evidence in great detail, in-

172 Trials conducted in open courts in China are heard by a single judge sitting with two "people's jurors" who are elected by their organizations or residential units to serve for a period of several years. Organizational Law of the People's Courts of the People's Republic of China, arts. 8, 9, 35-37, 1 FKHP 123, 124-25, 132 (1955), English translation in A. BLAUSTER, supra note 156, at 131, 133, 142-43. For illustrative discussions, see Bring Out the Full Function of People's Assessors, Kuang-ming Daily (Peking), Jan. 25, 1956 (editorial), English translation in SCMP No. 1228, at 4 (1956); Questions Pertaining to Election of People's Assessors Answered, Heilungkiang Daily (Harbin), Mar. 25, 1958; Sun Shih-k'ai, People's Juror Wang Lan-ying, People's Daily (Peking), Sept. 19, 1961. 
dicating that they pointed to a conclusion that the wife had misbehaved, and then adjourned the court.

Thereafter, a third and final session of the court was held, to which only the parties were summoned. The wife continued to deny her extramarital relations, but the judge announced that the evidence was sufficient. He granted the divorce, and awarded custody of the child to the husband. ${ }^{173}$

This emigré account is consistent with reports by Western visitors to China who have observed Chinese courts in divorce cases. In one case reported by an English observer, a woman school teacher sought a divorce because of constant mistreatment by her husband. Plaintiff wife's administrative superior, the principal of the school where she taught, was called on by the judge and vigorously criticized the husband's "feudal background" and his mistreatment of his wife."

(b) Mediation within Rural Communes.-Thus far, discussion of mediation in organizations has been confined to the urban context. However, mediation in government bureaus in the countryside and in economic enterprises outside major cities can be expected to show the characteristics already described. Most of China's population lives in rural communes where dispute resolution also bears considerable resemblance to the processes within organizations described above. State and Party apparatuses reach down to the $h \operatorname{sien} n^{175}$ and through it down to the commune.

173 Other emigré accounts also emphasize the involvement of organizations in attempts to resolve their members' marital disputes. For example, a former labor union cadre in a large economic enterprise was involved in an attempt to settle a divorce case in Canton in 1960. The husband, a cadre, had been sent from his job in the enterprise to the countryside, to work in a commune as punishment for his "rightist" political views, leaving his wife and three children in the city. The wife was employed in a factory. Finding it hard to make ends meet on the husband's salary, which had been reduced when he was sent to the countryside, she requested a divorce. The labor unions of the husband's place of employment and the wife's factory, together with the street busimess office in the neighborhood where the couple had lived together and where the wife still lived, attempted to dissuade the wife, arguing that she should attempt to "educate" her husband politically rather than divorce him. If he was receptive to such education and showed improvement, he would be allowed to return to Canton and take up his former employment, thereby improving the family's economic position. The wife argued that her husband could not be reformed, because he was of "landlord" class origin, and lacked a good "political standpoint."

Repeated efforts by the labor union and street business office cadres failed to dissuade the wife, and the cadres at her place of work reluctantly decided that the matter should be taken to a court, which the wife did by writing a letter to the local People's Court. The court attempted at several sessions to reconcile the couple [the details of the court proceeding were not available], but met with no success. The court finally issued a divorce decree, grounding its decision on the couple's different "political standpoints."

174 F. Greene, Awakened China 206 (1961).

175 For a detailed study of hsien government and Party organization, see Barnett \& Vogel, A County in A.D. BARNET, supra note 65 , at 107-309. 
Rural households are grouped into production teams which in turn form production brigades that may include several villages; a varying number of brigades makes up the commune. ${ }^{176}$ Commune, brigade, and teams are administered by committees headed by commune, brigade, and team chiefs. In addition to its functional units which divide responsibility for sucli matters as agricultural production, finance, culture and education, commerce, water conservation, and industry, each commune had a political-legal department and a police station which is comparable to the urban neighborhood police station. ${ }^{177}$ Each brigade and team also has security defense committees or single activists responsible for public security work. ${ }^{178} \mathrm{Few}$, if any, police cadres are permanently stationed in brigades or teams so the tasks they would normally perform are handled by security defense committeenien and brigade and team leaders. The Young Communist League and the Women's Association also have organizations in the commune. ${ }^{179}$ Party organization, of course, also permeates the commune and its subordinate units. ${ }^{180}$

Although communes have nediation committees with members from each brigade, documentary sources and emigré interviews alike suggest that the bulk of civil disputes are handled by team and brigade leaders or by security defense activists. ${ }^{181}$ Even when mediation committees meet, team and brigade leaders are extremely influential in determining

176 The number of communes, brigades, and teams bas fluctuated. A recent official Communist Chinese figure puts the total of communes at 74,000, and a Nationalist source states that there are over 700,000 production brigades. These figures are quoted in Skinner, Marketing and Social Structure in Rural China, 24 J. of Astar Studies, 363, 397, 399 n.279 (1965). On commune organization see J.W. LEWIS, supra note 70, at 204-43; F. Scrururass, supra note 66, at 474-97; Skinner, supra at 382.

A large commune in South China that has recently been studied has 11,000 households and a total population of more than 60,000 people. A.D. BarNerT, supra note 65 , at 339 . It is made up of 16 brigades; a typical brigade has between 500 and 600 households formed into 24 production teams. See id. at 363 .

177 See A.D. BARNET, supra note 65, at 390.

$178 \mathrm{Id}$.

179 Id. at $345,366,368-70,381$.

180 See id. at 343-49, 364-65, 367-72, 418-19.

181 Discussions of commune cadres' roles have specifically mentioned dispute settlement. See, e.g., Yeh Ku-lin, Fully Develop the Role of People's Mediation Work for Serving the Construction of Socialism, PoLITICAI-Legat Researce No. 4, at 12 (1964) (commune management committee), English translation in SCMM No. 461, at 1-2 (1965); Showing Concern over the Livelihood of the Masses, Consulting Them when Problems Arise, Women of China n.2 (1961), English translation im U.S. Consulate General, Hong Kong, Extracts from Chova Maindand Magazines No. 261, at 22-23 (1961) (team leader); $A t$ Yangtan Commune Headquarters, Pexnng Review, Mar. 11, 1966, at 18, 19-20: "The [commune office] was sometimes like an extempore judge's chambers. Two or three persons would come to lay complaints or get a quarrel or dispute settled. The commune cadres mediated, calmed the excited and soon everyone departed satisfied. . . . Minor problems are settled on the spot; larger ones go to the CMC [Commune Management Committee]." 
the outcome of the dispute. ${ }^{182}$ Considerably fewer cases go from the commune to the "basic-level" people's court at the hsien level than from the urban neighborhood to the urban district people's court.

\section{Comparison of Mediation in Different Contexts}

Although information available on dispute resolution in organizations and rural communes is even nrore scattered and impressionistic than information on urban neighborhood nediation, there are indications that dispute resolution in both urban organizations and communes differs sonrewhat in style from mediation in urban residential areas. The differences reflect the lack of formal differentiation of inediation from other tasks within organizations and the shight extent of such differentiation in communes. Additional factors in the contrast are the focused purposes which organizations have in contrast to urban neighborhoods and the partial barrier between organizations and the society outside them. The result, depending on the nature of the organization, may be nore-or less-infusion of pohtical considerations into dispute resolution.

Organizations such as the Party and the Young Comnunist League which display great cohesiveness and inamtain an even "psychic" distance from other sectors of Chinese society, ${ }^{183}$ nnay subject dispute resolution to more overt and intense politicization. This is particularly true when

182 "Though mediation continued to be important in Brigade $B$ and Commune $C$, no formal committee for mediation existed in 1964, and the top Party and public security authorities tended to monopolize this role as they did all others relating to basic law and order. In Brigade $B$, all the brigade's cadres were, in a sense, regarded as potential mediators and at one time or another most of them had actually inediated disputes. The principal person among the cadres to whom minor property and family disputes and the like were taken was the brigade public security chief. Needless to say, because of his great power and prestige, his recommendations were extremely authoritative. He did not handle all types of disputes in Commune $\mathrm{C}$, however; some, including divorce cases, were automatically referred to the Commune Political and Legal Department.

"It was symptomatic and symbolic of the pervasive way in which the Party and public security authorities had intruded into people's lives in Commune $C$ that they had come to dommate even the function of mediation, a function which traditionally in China had been fairly informal and autonomous and was generally independent from the more powerful formal instruments of state power." A. D. BARNETr, supra note 65, at 403.

183 See A.D. Barnetr, supra note 65, at 35-36: "According to a former non-Party cadre . . . a clear 'psychic distance' was consistently maintained between the Party members and non-Party cadres. Non-Party cadres were fully conscious of the power and authority conferred by Party membership, whatever the salary rank of an individual. The regular closed Party meetings and Party members' special access to certain classified Party materials were constant reminders of their special position. Non-Party cadres felt, moreover, that Party members were continuously judging them. Party members were wary about forming close personal relationships, even within the office, with non-Party cadres, perhaps partly because of the Party's suspicion that such relationships might contribute to the formation of undesirable groups or cliques (chi t'uan). Outside the office there was relatively little social contact between Party members and non-Party cadres, even though they often lived in close proximity in government-run apartments." 
leaders of these organizations consider that a dispute involves organizational discipline or the organizations' relations with the rest of society. For example, former policemen have stated that policemen's disputes with ordinary citizens may be taken very seriously if the dispute is brought to the attention of authoritative police cadres, because such disputes are considered to involve basic questions of relations between police and masses. Furthermore, disputes between Party members and nonParty members may, under some circumstances, involve the Party members in considerable trouble with their Party organizations, as in marital disputes involving a Party member's extramarital relations. An emigré describes a provincial Party school for relatively high-ranking Party members as a particularly closed institution in which disputes were regarded as threateming the organization. The marital disputes and peccadillos of cadres attending the school could lead to administrative punisliments-not to mention expulsion from the Party-which could have considerable impact on the offender's subsequent career.

However, some organizations may attenuate the political issues which disputes are thouglit to involve. Neighborhood mediators, whether cadres or activists, are supposed to learn as much as possible about residents in the areas for which they are responsible in order to be able to assist police and other authorities in dealing with problems involving such residents. It follows that they can spend mucl time talking to the residents and becoming acquainted with them-"penetrating the masses," in Party jargon. However, cadres and activists in organizations are charged with fundamental tasks more directly related to the functions of the organization, such as maintaining the output of factories. The Chinese Communists themselves, especially in recent years, have not drawn such a distinction. Quite the contrary, organizations and the cadres who lead them are expected to be closely concerned with the personal lives, "ideology," and "viewpoint" of their members. However, there are indications that in practice mediation in economic enterprises may lack some of the intensive mobilizational style of its extraorganizational counterpart. Work supervisors and labor union cadres may often be too occupied with tasks related to the productive goals of their enterprise to engage in lengthy attempts to persuade one or both disputants of error or to mobilize other workers to engage in such activities. Furthermore, since dispute resolution is not differentiated from other tasks, cadres may simply treat disputes as administrative matters which they ought to decide in the ordinary course of business. As a result, they decide rather than mediate disputes. Illustratively, a highly intelligent former labor union cadre interviewed in Hong Kong regarded disputes between workers 
or within their families as demanding little different activity on his part than handling an injured worker's claim for labor insurance benefits.

While mediation within certain organizations may be somewhat more or less mobilizational than dispute resolution elsewliere in China, it certainly shares basic characteristics and functions. The next part of this Article attempts to identify the functions of mediation in China today based on the foregoing description of how mediation is carried out in the different contexts in which it is conducted.

IV

THE FUNCTION OF MEDIATION IN COMMUNIST CHINA

One function of mediation, of course, is to resolve disputes. It is intended to help maintain public order by inhibiting and ending disruptions of the peace and of the orderly functioning of economic activity. Mediation is also intended to end bad feeling between individuals by offering them a readily available and highly informal mode of settling disputes.

However, mediation in Communist China also serves three other identifiable functions which sometime overshadow dispute settlement. First, it serves to articulate and apply the ideological principles, values, and programs of the Chinese Communist Party and helps mobilize China's people to increase their commitment to Party policies and goals. Second, it serves to suppress rather than settle disputes between individuals which are regarded, at the very least, as unwelcome social conflict interfering with construction of a strong socialist China. Third, it supplements other means of control exercised by the state and Party apparatus.

\section{A. Mediation and Mobilization: Politicization of Dispute Resolution}

Mediation in China today clearly reflects the decisive impact of Maoist ideology. The incorporation of salient ingredients of Maoism into the mediation process is demonstrated by the identity of mediators and the values and standards they are supposed to use in settling disputes. The Party has tried to select politically "progressive" activists as urban street mediators; much mediation in neighborhoods and all mediation in organizations and courts is done by cadres; cadres and activists together form China's revolutionary elite.

\section{Role of Mediation Committees in Implementing Economic Policies}

Since the promulgation of the "provisional rules" on mediation committees in 1954, their role in supporting production and implementing 
economic policies has been emphasized constantly. In the first years of their existence, the Communist Party used mediation committees to advantage in the countryside, employing them to support its drive for agricultural cooperativization. After the stormy land reform of 19501952 had redistributed much land among 300 million peasants, the Communist Party began to organize peasants into mutual aid teams to raise productivity by pooling labor, implements, and draft animals. ${ }^{184}$ The mediation committees were acclaimed for their role in benefiting production by settling quickly disputes among peasants over allocation and usage of water, timber, and tools. ${ }^{185}$

Later, from 1955 to 1957 when rural collectivization was accelerated in China and peasants were organized into rural cooperatives, the collectivization campaign was announced as the "central work" which mediation was required to support. ${ }^{186}$ The resolution of disputes within peasant teams, the nuclei of the cooperatives, was popularized by mediatorsespecially disputes in which peasants accused each other of neglecting collective interests. ${ }^{187}$ Mediation committees aided "unity" when peasants disagreed on the desirability of joining or remaining in cooperatives by "persuading" doubters of the advantages of cooperativization. ${ }^{188}$ Some mediation committees were praised for being even better than the cadres they were supposed to assist. ${ }^{189}$ When China's agriculture was further collectivized with the creation of rural communes in 1958-1960, mediation

184 See generally K.R. Walker, PlannINg In ChInese Agriculture 3-6 (1965).

185 Progressively Do Well People's Mediation Work, Increase Unity in the People, Facilitate Production and Construction, Southern Daily (Canton), Sept. 10, 1954; Positively Serve Mutual Aid and Cooperation in Agricultural Production, Kuang-ming Daily (Peking), June 5, 1955; A People's Mediation Committee Which is Active on the Agricultural Production Line, id., Aug. 17, 1955; Positively Serve Mutual Aid and Cooperation in Agricultural Production, id., Aug. 11, 1955.

186 See, e.g., Ch'en Kuan-hua, The Experience of the People's Mediation Commillee of San-Huai Hsiang, Kuang-ming Daily (Peking), Mar. 29, 1955; The People's Mediation Committee of Hsien-ho Hsiang, Hai-an Hsien, Kiangsi Province, id., June 5, 1955; Positively Serve Mutual Aid and Cooperation in Agricultural Production, id.

187 See, e.g., A Hsiang People's Mediation Committee Which Serves Production, Kuangming Daily (Peking), Oct. 14, 1955.

188 See, e.g., Hai-Teng Hsien's More than Four Hundred Mediation Comnitlee Members: The Good Consequences of Helping the Masses Settle Dispules, Fukien Daily, Dec. 4, 1956; Mediation Committees are 'Peacemakers' for the People, Southern Daily, Feb. 27, 1957 (disputes within families over joining cooperative); People's Mediation Committees Everywhere: Positively Serve Agricultural Mutual Aid and Cooperation, Kuangming Daily (Peking), Mar. 29, 1955 (cooperative members persuaded to remain in cooperative).

${ }^{189}$ See, e.g., The Rural Mediation throughout this Province Gains Conspicuous Success, Fukien Daily, July 3, 1955; Positively Serve Rural Assistance and Cooperation in Rural Work, Kuang-ming Daily (Peking), Aug. 17, 1955 (cadres asked four families to withdraw from cooperatives; after mediators persuaded would-be withdrawers to remain, cadres who had asked them to leave criticized for "undemocratic work style.") 
committees were used to extol communal living, increase commune members' commitment to communalization, and reduce disputes which interfered with production and the task of organizing and administering the new communes. ${ }^{190}$ More recently, commune mediators have been encouraged to curb "spontaneous capitalism" among peasants and to assist Party and administrative leaders to mobilize the masses to sign public pacts. ${ }^{101}$

The mediation comnittees supported economic policies in the cities as well as in the countryside. In one reported case, after a factory worker became involved in a series of accidents at work, a mediation committee investigated and found that he was preoccupied by domestic quarrels with his wife; the committee advanced both family unity and production by settling the dispute. ${ }^{192}$ From Canton it was reported that after a mediation committee investigated a landlord-tenant dispute, it was discovered that the landlord lacked money to pay real estate taxes because his tenants were not paying their rent. The mediators convinced the tenants to pay rent and the landlord to pay taxes. ${ }^{193}$ Also in Canton, when mediation committees discovered that urban households contained unemployed people who had left the countryside, they "nrobilized" them to return to their villages. ${ }^{194}$

\section{Politicization of Mediation Standards}

The political objectives of mediation have not remained unchanged nor have they been carried out with consistent intensity. Mediators were apparently most active from 1955 to 1957 when they urged peasants

In one case, twelve households prepared to withdraw from a cooperative after a bad harvest. "Some cadres had a passive attitude," and would have permitted the withdrawal, but an earnest lady mediator made them stay. First she selected two peasants from among the would-be withdrawers and persuaded them that the bad harvest bad nothing to do with cooperativization and that a good harvest was expected during the coming year. Then she enlisted her husband to help in the "persuasion and education" of the two men, who changed their minds, and finally she organized other mediators to convince the rest of the group to remain in the cooperative. Mediation Chairman Yüan Ts'ai-ying, Great Masses Daily (Chinan), June 17, 1957.

100 See, e.g., Chang Jui-chi, Strike Incisive Blows at the Enemy, Handle Disputes Promptly, and Safeguard the Solidarity and Development of the People's Communes, Polmicat-Legal Researci No. 6, at 59 (1958), English translation in JPRS No. 813-D, at 28, 31 (1959); Ts'ui Ch'eng-lısuan, How We Safeguarded the Security of the Welfare People's Commune, Poumtical-Legal Researce No. 6, at 61 (1958), English translation in JPRS No. 813-D, at 34, 38 (1959).

101 Yeh Ku-lin, supra note 144, at 16, SCMM No. 461, at 7-8.

102 Strengthen Mediation Work, Reinforce the Internal Solidarity of the People, Tsingtao Daily, April 24, 1956.

193 A Ball of Thread with a Thousand Knots, Mediation Committee Unties Them, Canton Daily, July 18, 1957; City Mediation Committee Performs an Important Function in Handling Cases, id. 704 Id: 
to join cooperatives and workers to contribute to socialist construction. They seem to have had a brief but heightened role during the organization of the rural communes, but since the communes were formed they have not been linked very closely with the implementation of specific policies or campaigns. These variations reflect more general changes in Chinese politics, but they should obscure neither the explicit links between mediation and policy nor the ubiquitousness and activism expected of mediators, which together demonstrate the standards whicls the Party hopes to apply universally in the resolution of disputes. In a word, the standards have been politicized; that is, the issues between the parties, alternative solutions, and even the mere occurrence of the dispute have been invested with political significance. Whether or not mediators actually articulate political issues when they resolve specific disputes and what range of effects politicization may have on dispute resolution are separate problems discussed below. The goals and frequent effects of pohticization are very clear. Issues whicl the disputants consider to be purely personal may be transmuted by mediators into much larger and more abstract issues of national policy, and disputes may be resolved to assist implementation of policies.

The consequence of politicization is that dispute "resolution" may more accurately mean not so much settlement of particular disputes as their oversimplification into abstract political generahzations. To "resolve" means, at least to Western lawyers, to "answer" or to "solve," but it also means to "reduce to simpler form." Both meanings are pertinent here. Thus, a husband who mistreats his wife is characterized by a judge as "feudal;"195 a mother-in-law who squabbles with her son's wife is told that the disagreements are caused by "old ideology;"196 a young married couple unable to adjust their married life to their employment schedules is told that they must "serve national construction;"107 a landlord is told that for the good of the nation he should help rather than collect rent from his tenant; ${ }^{108}$ a wife is told first that she cannot divorce her husband but must "educate" him politically, and then that she may divorce him because of his "bad political standpoint."100 In each case, the disputants' personal grievances were transcended and overwhelmed by a larger issue of political policy.

\section{Effects on Disputants of Politicization}

Politicization of a dispute is not necessarily inconsistent with its resolution in a manner quite acceptable to one or both of the parties. For

\footnotetext{
195 See p. 1328 supra.

190 See text accompanying note 150 supra.

197 See p. 1326 supra.

108 See p. 1327 supra.

109 See note 173 supra.
} 
example, when a liusband beats his wife and renders their conjugal life insupportable, the wife may be successful in a divorce action whether or not her husband is labeled as a "bourgeois" with "feudal ideology" and "bad political standpoint." This is not to say that these political terms are merely conclusory; it should be apparent that political principles and categories may furnish directly applicable standards for decision.

The Maoist ideal of politicization and its realization in practice are, of course, divergent like goals and practice in any legal system. But enough information is available on mediation and its political qualities in practice to permit meaningful evaluation of how political considerations actually affect the resolution of disputes. It appears that mediation, which has hitherto been discussed as a unitary concept both in China ${ }^{200}$ and the West, ${ }^{201}$ may not operate identically in all sectors of Chinese society. Thus, from the standpoint of politicization, mediation in residential units and organizations may well differ. The different preoccupations of a housewife-mediator and a bureaucrat-mediator will be reflected in the exhortation which they engage in-or eschew-in settling disputes. This rough distinction requires further refinement, since dispute resolution within organizations may vary with the extent to which the organization itself has highly political purposes and internal discipline.

Politicization cannot be total and may often be absent altogether. Not all mediators are persistent and patient model mediators, ready to mobilize neighbors or fellow workers to "educate" disputants and each other; some mediators neglect political considerations, show favoritism, accept bribes, or attempt to settle disputes in a spirit of compromise without resort to political standards for decision. If these defects in what the Communists call "work style" did not exist, they would not have been extensively discussed and condemned as they have been consistently for the past twenty years. Deviant, "incorrect" styles of mediation may, of course, produce solutions to disputes quite satisfactory to the parties. When a mediator eschews a political approach and tries instead to bring the parties together on some mutually acceptable ground, he may succeed in reaching a successful compromise, even if in the Party's view lie deviates from proper policy by engaging in "unprincipled," that is, unpoliticized mediation, which stresses compromise for the sake of ending conflict.

Even when political factors are infused into disputes, the effect is often less than decisive; the Communist Party must struggle not only against neglect of its goals, but against perfunctory support of them. Thus, political issues may be functionally quite meaningless, as when mediators suggest workable compromises which meet the issues the

200 See, e.g., Yeh Ku-lin, supra note 144.

201 See, e.g., Cohen, Chinese Mediation, supra note 14, at 1202-03. 
parties thought to be involved in their dispute, give rehef to the party who thought he was aggrieved, and justify the results on such abstract grounds as "Communist morality" or the need for comrades to "unite" for the sake of the revolution. An illustrative dispute is the following:

In a large city in South China in 1959, an employee of an enterprise rented a room from the agent of an overseas Chinese ${ }^{202}$ for ten yüan monthly. ${ }^{203}$ It was understood that the tenant would also have the use of another room in the same apartment, except when the landlord's agent wished to use it. Soon afterwards, additional members of the tenant's family came to live with him, and he put them up in the second, "empty" room. The agent demanded that the rent be increased to twenty yüan monthly, because the tenant and his family were now occupying twice the space rented. The tenant refused, arguing that the agent could still sleep in the second room whenever he wanted. The agent demanded that the family vacate the premises and refused to accept ten yüan monthly.

When the tenant and his family refused to move, the agent went to the local street business office, which sent a woman to mediate the dispute. The mediator, who was addressed by the two parties as "Sister" Chang, heard the parties explaim their positions as stated above, and then said that it appeared to her that the tenant was really living in two rooms, not merely the one for which he was paying rent. She suggested that she did not think that it was right for the tenant to pay no rent for the second room; nor did she think it was right for the agent to make them all move because of the disagreement. She suggested that it would be best if both sides "yielded a little" (jang $i$-tien) and arrived at a compromise. The agent adamantly refused to agree [in a Hong Kong interview, the former tenant stated that lie thought the agent suspected Sister Chang was favoring the tenant, a resident of the same street, against an absentee landlord] and initiated proceedings in the district people's court, which summoned both parties.

When the tenant went to the court on the appointed day, he showed his letter to a policeman, who directed him to an office. In the office was a cadre who identified himself as the person in charge of mediation (t'iao-chieh chu-jen) and a clerk. The agent arrived, and the mediator heard both sides, interrupting to ask questions. Then he proposed a solution.

The cadre stated that since the tenant was a cadre and the landlord an Overseas Chinese, the two nen had obligations to help and understand each other in the interests of the revolution. He pro-

202 Until the "Great Proletarian Cultural Revolution," it was common for absentee overseas Chinese to continue to own urban dwellings which they were permitted to rent through local agents. See, e.g., Overseas Chinese Dependents Work Committees in Canton, Ta kung pao (Hong Kong), Jan. 14, 1957, English translation in SCMP No. 1455, at 16 (1957).

203 The official Chinese exchange rate is 2.617 yüan to the U.S. dollar, A. Ecksters, Cosmonist China's Economic Growtir and Foretgin Trade 294 (1966). 
posed that the tenant pay an additional four yüan monthly for the use of the second room, and that the parties continue to observe their agreement that the tenant and his family would move out of the room whenever the agent wished to use it. The parties agreed to this proposal, and their dispute was thus resolved.

In this dispute, the street mediator merely sought to effect a compromise without reference to any political considerations. Moreover, she phrased her suggestion in a manner much more consistent with traditional, rather than Communist, modes of resolving disputes by mediation when slie suggested that the parties end their dispute by each "yielding a little."204 The political criteria articulated by the mediator at the court are not without significance since they imply that he decided neither party had a "bad" class or pohtical background requiring the use of other political criteria. However, so far as the parties were concerned, it made no difference whether the solution to their dispute was phrased by the street mediator or the court mediator; the solution was still a compromise that permitted the tenant to occupy the premises without doubling his rent and the landlord's agent to increase the rent. The politicization of the dispute was hardly decisive. Moreover, it suggests that if the disputes in which pohtics is neglected are taken together with the undoubtedly greater number of cases in which politicization is superficial and meamingless, it would seem that considerable mediation is for all intents and purposes "unprincipled."

Of course, pohtical issues may be more sharply focused on the parties and their dispute. In some cases there still may be no serious implications. Thus, in the account of model mediator Li Erh-ma's activities summarized above, ${ }^{205}$ it was not serious for Mrs. Wang to be told that her trouble with her daughter-in-law lay in her own "old ideology." In other cases, the issue involved in a dispute is so clearly related to a specific policy that it would be difficult to avoid invoking the policy. When a mother-in-law tried to prevent her daughter-in-law from joining an agricultural cooperative because she feared that the daughter would be placed in improper proximity to men other than her husband, it was hardly surprising that a mediator and an activist for women's work persuaded the tradition-minded woman that her "thought" was "mistaken."208

When important Communist policies which have been fully implemented are involved, disputes may be so deeply politicized that political issues not only decide the dispute, but also produce further consequences

204 See p. 1291 supra on the importance in traditional China of the notion of "yielding." 205 See text accompanying note 150 supra.

206 How I Carried Out Mediation Work, Shensi Daily, Mar. 25, 1957. 
for at least one of the parties. For instance, persons stigmatized as "enemies" or "bad elements" with a "bad class origin" may find resolution of their disputes with other persons not so disadvantaged a most unpleasant experience. Illustratively, when husbands of "landlord" or "bourgeois" background are accused by wives of "worker" or "peasant" origins of mistreatment, they risk severe criticism, sometimes in large groups led by the women activists who seem to comprise most of China's urban mediation committee members. Indeed, several emigrés have indicated that aggressive wives of "better" class origin than their husbands use this political factor affirmatively in seeking divorce actually based on other reasons. Since it is easiest to obtain a divorce because a "bourgeois" liusband has behaved "feudally," a wife who prefers another man to her husband may attempt to end the marriage by raising political rather than other more basic reasons.

Disputes often lead to sessions of exhortation and embarrassing public criticism in disputants' homes and places of work. It is not surprising, therefore, that some people try to avoid mediation by activists and cadres. Emigrés with "bad class origin" stated that they tried to avoid contact with activists; if disputes arose within the family or with neighbors, they preferred, in their own words, to "bear with" or "be patient with" the unpleasantness rather than to expose themselves to lectures and criticism from mediators. Indeed, so objectionable can the mediators' activism become, that, according to several former policemen, disputants who felt deeply that they were in the right preferred to have a policeman settle their dispute. Such disputants thought that mediators talked too much without deciding their problems, and they preferred to have a more authoritative person with other duties besides mediation impose a decision. ${ }^{207}$

There is not enough information to go beyond these tentative differentiations on the extent of politicization. However, at this juncture it is possible to suggest, on the basis of a synthesis of documentary sources and emigré interviews, that considerable politicization has occurred, resulting in much dispute resolution in highly political terms with the primary aim of implementing and furthering Communist policies.

\section{B. Mediation and Dispute Suppression}

Politicization of disputes means that conflict which individuals view as personal and centered on narrow issues should be perceived quite differently by mediators. Politicization requires the mediator to apply

\footnotetext{
207 On the other hand, several former urban residents who recalled avoiding activists also avoided contact with poicemen, saying that they; too, often felt it necessary when settling a minor civil dispute to regard the parties as "objects" of persuasion.
} 
to dispute resolution generalized values which stress commitment to Party and national goals and to collective efforts to attain them. As a result, mediators, whose views of the issues and possible solutions of a dispute differ radically from disputants' views, may give more time and effort to fashioning a political solution-changing the "thought" or "standpoint" of the disputants-than to settling the smaller issues whiclr precipitated the dispute. Consequently, the dispute may be suppressed in one of two ways. Primary dispute suppression occurs when resolution of the parties' differences is submerged in the mediator's application of abstract principles, stressing noncontentiousness and mutual assistance for the sake of national unity, collective living, and increased production. Thus, spouses who themselves cannot reconcile their sexual life with their hours of work are told by a judge that they cannot obtain a divorce, but are given no reason or alternative solution because national economic needs override their own. ${ }^{208}$ A "bourgeois" creditor is told that lie cannot expect a cadre to pay the rent because all economic classes must unite to assist the national economic effort. ${ }^{209}$ Two men who fight because one accused the other of theft are told that they are "comrades" and must help each other. ${ }^{210}$ Because settlement of disputes in this style is important, mediators who deviate from it liave been criticized. ${ }^{211}$ As a result, however, parties cannot obtain a meaningful settlement of their original controversies. Because the original issues may continue to exist after the dispute ends, this is suppression rather than resolution of the dispute.

Secondary dispute suppression occurs when disputants avoid mediation by activists or cadres because they feel it will not resolve their difficulties. Thus, emigrés have told of avoiding mediation for fear of the mediators' lectures and exhortations. Similarly, they feared involvement with street activists, whom they regarded as ineddlesome agents of the police, and therefore as representatives of the control apparatus. ${ }^{212} \mathrm{Be}-$ cause of these anxieties, disputants may sometimes prefer private rather than official mediation. Althougi generalizing about the identity of these private mediators is difficult, they are probably friends or relatives who, whatever their activities and employment, can be trusted by the disputants not to inject unwelcome political factors into the dispute. However, cadres' and activists' political roles do not so exclude personal relationships that disputants cannot sometimes seek mediation because of the mediator's acquaintance with the parties rather than because of his posi-

\footnotetext{
208 See p. 1326 supra.

209 See p. 1327 supra.

210 See p. 1324 supra.

211 See text following note 91 supra and text accompanying note 126 supra. .

212 See, e.g., F. SchurdanN, supra note 66 , at 378 .
} 
tion. ${ }^{213}$ In addition to this diversion of disputes away from cadres or activists, emigrés have stated that they sometimes thought it best to "forbear," thus avoiding any protest or disagreement over fancied wrongs. Therefore, although the extent of such mdirect dispute suppression cannot be determined, the politicization of mediation seems to prompt some persons to avoid mediation altogether.

\section{Mediation as an Instrument of Control}

Mediators, being activists or cadres, belong to the state and party apparatus whose most important goal is to maintain and strengthen Party control. The closeness of activist mediators to both the urban police and the Party has been stressed frequently by the Chinese press ${ }^{214}$ and corroborated by emigrés. Mediators are intended to act as supplementary sources of information on the activities and "ideology" of disputants and as agents to locate and inhibit antisocial conduct. Thus, they help repress "enemies" of the "people," and "persuade" "bad elements" to reform. In this connection, they have been repeatedly urged to maintain their vigilance against such harmful elements and to report serious acts committed by them to the police. ${ }^{215}$

The extent of the control exercised by mediators varies with their power to invoke sanctions. Mediators wield varying quantities of power in the context of a range of devices used by the Party to elicit a voluntaristic response from China's people.

If a citizen is reluctant to volunteer, the regime first attempts to persuade. The citizen who does not respond to the appeal for volunteers is presented with rational arguments on why the regime needs volunteers. The arguments presented in a citizen's small group and the visits of numerous activists urging him to volunteer may arouse some anxiety, but in voluntarism, properly practiced, there is nothing to suggest the use of force. The citizen being persuaded understands perfectly that threats lie behind these rational arguments, but they remain implicit. ${ }^{216}$

The sanctions deliberately kept in the background that back up the Party's persuasive efforts include further and more intense persuasion of a citizen who refuses to volunteer, criticism at small or large meetings,

213 See, e.g., the argument made briefiy against continuing to employ mediation committees on the ground that disputants preferred to have disputes settled by persons whom "they themselves trust and cadres who have prestige," and therefore asked such persons to settle disputes even if they were not mediators. Ch'ang Chen, The Continued Existence of People's Mediation Committees is not Necessary, Kuang-ming Daily (Pelking), July 16, 1956.

214 See, e.g., notes 146 \& 148 supra.

215 See, e.g., Yeh Ku-lin, supra note 144, at 14, SCMM No. 461, at 5.

216 Vogel, supra note 73 , at 171. 
adverse entries in a dossier he never sees, denial of welfare benefits, or more formal penal measures. ${ }^{217}$ Emigrés indicate that once activists or cadres notice a dispute and "request" the parties to mediate, they are loath to decline, fearnig that renewed and insistent "requests" will follow.

Activists and cadres acting as mediators in urban neighborhoods, rural communes, or organizations are part of the Party-created machinery for persuasion and sanction, especially when disputes involve important policies such as "oppression of women" by reactionary husbands," spontaneous capitalism" among peasants, or interferences with production. These issues, although not specifically related to a large-scale campaign calling for mass response, nonetheless call for persuasion and exhortation backed up by sanctions. In disputes related to major campaigns, mediators may exert even more direct control; for example, mediators "persuaded" peasants to join agricultural cooperatives ${ }^{218}$ and to cease complaints against collective living in the rural communes. ${ }^{219}$

There are considerable variations in mediators' persuasiveness and authority to invoke sanctions. Urban neighborhood mediators are frequently looked down on and unlieeded by disputants who have been told repeatedly by the Party that they may take their disputes to courts. However, while mediators themselves may lack coercive power, they report to policemen and other cadres and can trigger more authoritative action leading to criticism or some greater sanction. In rural communes and organizations mediation is done by cadres who combine "power to persuade" with power to invoke sanctions. Work supervisors and cadres in enterprises control demotions, reductions in salary, transfers, or entries of demerits on employees' dossiers. Thus, mediation and control seem more closely merged in organizations than in urban neighborhoods. Regardless of their milieu, however, mediators are integral parts of the mechanism of Party rule.

\section{V}

DISPUTE RESOLUTION IN TRADITIONAL AND COMMUNIST CHINA: TENTATIVE COMPARISONS

The Communists msist that mediation today is antithetical to traditional mediation and owes nothing to China's heritage of extrajudicial settlement of disputes. Despite this claim of a revolutionary rejection of the past, changes initiated by the Communists may meet considerable resistance, and older, "incorrect" ways may meld with new ones. More-

217 See Cohen, Criminal Process, supra note 2, at 490-92, for a description of the variety of sanctions.

218 See notes 188-89 supra.

210 See note 190 supra. 
over, the Chinese Communists themselves may reflect and utilize traditional Chinese attitudes and patterns of behavior.

Traditional and Communist China share a marked and striking preference for extrajudicial resolution of disputes by mediation. The foregoing survey of the philosophy and practice of dispute resolution in China before and since the establishment of the People's Republic forms the basis for some comparisons. These comparisons strongly suggest that the Chinese Communists, beginning with a quite untraditional view of social conflict, have, by reordering the role and functions of mediators, fundamentally changed the purpose of dispute resolution by mediation. Although some continuities are detectable, they should not be exaggerated. In short, so far as the the purpose of the institution is concerned, change outweighs continuity; to a lesser extent practice also departs dramatically from tradition.

\section{A. Continuities}

\section{Survival of Dispute Settlement Aimed at Compromise}

Traditional modes of dispute resolution which stress compromise still exist to some extent in China today. The Communists' constant criticism of mediation conducted merely for the sake of compromise indicates that despite substantial success in structuring mediation to accomplish highly political purposes, traditional patterns tenaciously persist. Thus, a mediator who urges disputants to a rent dispute to "yield" (jang) a little, ${ }^{220}$ or who seeks to reconcile an estranged couple by urging that a "harmonious family" is an important foundation of daily life, ${ }^{221}$ is echoing traditional values stressed over centuries of Chinese history. ${ }^{222}$ This is but a particular manifestation of a larger problem - the endurance of institutions which the Communists have worked hard to overthrow and reorder. ${ }^{223}$

The Communists have consciously opposed use of the traditional media-

220 See the account at p. 1344 supra.

221 How I Carried Out Mediation Work, Shensi Daily, Mar. 25, 1957. In another dispute, the same mediator succeeded in turning a quarreling family into a "harmonious family."

222 See note 20 supra, on the Chinese virtue of jang.

223 See, e.g., Skinner, Marketing and Social Structure in Rural China, pt. III, 24 J. Asian Studies 363, 386 (1965): "As of 1958 ... despite a decade of preachment about proper socialist or, if you will, universalistic primciples, bonds of common origin ( $t$ 'unghsiang) were still invoked by the peasant in seeking favors from the authorities, kinship ties (t'ung-hsing), for instance, still elicited cooperation where more rational appeals failed, classmates (t'ung-hsïeh) were often truer comrades than fellow Party menubers, and within the cooperative-farm-cum-village, the local leader who could manipulate these particularistic allegiances was often more effective than the outside cadremen." On the tension between the mass line and particularistic relationships see Lewis, The Leadership Doctrine of the Chinese Conmunist Party: The Lesson of the People's Commune, 3 AsIAN SURVEY 457 (1963). 
tional style. The old style was passive in emphasizing yielding; the new style demands activism. However, they have been unable to politicize completely the principles used to resolve disputes, the purposes of settlement, and the process of mediation. The Communists have been unable to make every mediator an activist or to elicit an activist response to every problem. Some kinds of disputes do not afford mediators opportunities to teach important political lessons. When a "feudal" husband beats his peasant wife, the lesson is plain, but when two persons of equally "good" class background squabble over a chicken, the "contradictions" are clear only to the most politically supercharged mediator. In such cases, where the need for struggle and a changed "standpoint" is less pressing, the parties have more leeway to bargain and compromise and to find a solution based on compromise, although cloaked in political rhetoric.

\section{Lack of Protection for Individual Rights}

Other resemblances between traditional and Communist modes of dispute settlement suggest continuity, but the resemblances are not directly traceable in a linear fashion. Communist practice, which resembles earlier practice, is not necessarily an extension of its predecessor; yet, earlier practice has conditioned it. This is because the Communists, taking advantage of gaps in the traditional Chinese approach to law, have adapted traditional attitudes toward the law to serve their own, much different purposes.

Traditional China neither knew nor valued legal protection of individual or group riglits by judicial or other organs of the state. Protection from or redress for violations of interests in person or property was usually accomplished, if at all, within the aggrieved person's group or class, and his riglits and remedies depended on the status flowing from his memberslip. The "rule of law" in traditional China connoted not protection of individual rights, but expansion of state power and inculcation of discipline in the inasses. ${ }^{24}$ The Communist Party has clearly benefited from the absence in traditional China of a legal system that protected individual rights. When the Communist Party gained control, no longestablished legal tradition argued against the exercise of absolute Communist power.

Moreover, the Communists have benefited from China's lack of a legal system with techniques for applying generalized standards and categories to fact situations. To be sure, the elaborate rules of $l i$ drew distinctions concerning status and the interrelations of persons with different status,

224 Schwartz, On Attitudes Toward Law in China, in Governatent UNDER LAW AND THE INdNIDUAL 27, 37 (Katz ed. 1957). 
and some of these distinctions were preserved in the imperial code. ${ }^{225}$ Absent, however, were techniques for interpreting and applying them through a judicial decision making process. ${ }^{226}$ The Confucian judge "will (within limits) simply think of the legal code as providing certain guidehines but in his judgement will rely very heavily on the unique features of the circumstances of the case."227 Even though mediators and judges may have been applying the $l i$ in concrete cases, traditional dispute resolution, particularly mediation, offered much latitude for concluding disputes on the basis of the "concrete qualities" of the parties, the "concrete situation," or "according to equity and the appropriateness of the concrete result." 228

If dispute resolution reflected traditional Chinese lack of concern with judicial techniques, it also reflected a basic lack of concern for using dispute resolution to guide future conduct. But mediation so oriented "dulls the citizens' sense of right, essential to the vindication of the law."220 Furthernnore, while mediation may act as a conservative force for maintaining older values as it did before the Communist rise to power, mediation is not necessarily conservative. It may also "allow a new regime to ignore the law in favor of its new policy, as happened in Japan in the 1930 's," ${ }^{230}$ and it may be "a ready handmaiden for authoritarian, official discretion." ${ }^{\prime 231}$ By handling disputes without developing close-textured universalistic criteria or techniques for applying them, mediation in China inhibited the development of basic rights, however minimal, which the individual could vindicate to give his existence greater predictabihty and stability. To some extent, traditional mediation left fertile ground in which the Communists could plant their own mutant variety.

\section{Combined Judicial and Administrative Activities}

- Perhaps a more fundamental similarity is reflected in Chinese Communist use of legal and other means for dispute settlement as administrative devices. In Anglo-American countries, dispute settlement by judges is considered to involve rules and a type of decision making distinguishable from the rules and decision making of other governmental officials. ${ }^{232}$

225 See Cohen, Chinese Mediation, supra note 14, at 1208; Schwartz, supra note 224, at $29-30$.

226 Cf. M. WEBER, supra note 18, at 101-02.

227 Schwartz, supra note 224 , at 34.

$228 \mathrm{M}$. WEBER, supra note 18 , at 149.

2292 D.F. Henderson, Conctuation and Japanese Law, Tokugawa and Modern 241 (1965).

$230 I d$.

231 Id. at 216.

232 See, e.g., H.M. Hart \& A. Sacks, The Legal Process: Bastc Problems in the Makniv AND Application of LAW 155-79 (1958), 
Neither traditional nor Communist Chinese theory or practice distinguishes judicial from admimstrative activities. Traditional magistrates discharged all governmental functions, including administration; Communist judges are cadres, that is, administrative and mobilizational leaders of a universal type. This continued commingling of functions has some implications for the role of law in the Communist Party's efforts to modernize China.

Max Weber's influential theories on bureaucracy suggest that modernization means increasing specialization of function and differentiation of roles in bureaucracies. ${ }^{233}$ Under this theory, dispute resolution by officials should become differentiated from their other functions. ${ }^{234}$ However, the history of public admimistration in Communist countries, whether in the Soviet Union, Eastern Europe, or China, teaches that modernization and industrial development may be promoted by a bureaucracy than can remain highly politicized and undifferentiated ${ }^{235}$ In China, moreover, law and administration were far more undifferentiated at the time of Communist victory than they were in the European Communist countries. China's traditional blending of law and administration has perhaps conditioned, in part, the Communists' lack of inclination to separate these activities. This is not because Mao thinks like China's former rulers, but because they left behind no institutional separation that might have been continued. They left behind undifferentiation; undifferentiation of another kind has taken its place. ${ }^{238}$

\section{B. Discontinuities}

Despite some continuity, it is the changes wrought by the Communists, both in ideology and institutions, that most compel attention. Preoccupied with ideas of struggle and change, the Communists have mjected them

233 The literature on Weber's theory of bureaucracy is immense. The core notion of the theory stressed in the text, of "modern" bureaucracy as the most differentiated, is derived from Weber's distinction between charismatic, traditional, and rational authority and the bureaucratic structure characteristic of each. M. WEBER, THE TEEORY OF SOcIA工, and Econontc ORganization 328-92 (T. Parsons ed. 1947). For a discussion of Weber's theory as it fits political modernization today, see J. LaPalombara, Bureaucracy and Political Development: Notes, Queries, and Dilemmas, in Bureaucracy AND POITICAL DeveropIIENT 34, 48-55 (J. LaPalombara ed. 1963).

234 E.g., 1 W. HoldsworTH, History OF ENGLISH LAW 231-42 (3d ed. 1922) (separation of legal and administrative functions of Exchequer in the thirteenth century).

235 See Beck, Bureaucracy and Political Development in Eastern Europe, in BuREAuCRaCY and Polmical Deveroparent 268 (LaPalombara ed. 1963); Fainsod, Bureaucracy and Modernization: The Russian and Soviet Case, in id. at 233; Vogel, Politicized Bureaucracy: Communist China (unpublished paper in author's possession).

236 Note, for example, the similarities between Chinese and East German unwillingness to differentiate between law and administration and between the theories used to justify them. See O. KIrchintumer, Polmical Justice 259-303 (1961). 
into the processes of dispute resolution to make radically new virtues dominate calmer, older ones.

\section{The Different Organizational Context of Mediation}

Mediators in traditional China were clearly not regular members of a tightly-meshed state apparatus. As already indicated, the traditional Chinese state reached down only imperfectly to the society it governed, and dispute resolution lay largely outside the activities of the magistrates. The gentry, to be sure, shared the intellectual background and values of the officials and had vital interests in the stability of a government which protected their own wealth and prestige. Therefore, when settling disputes, advising magistrates, or helping to enforce magistrates' decisions, the gentry acted in a sense as auxiliaries to the formal apparatus of government. In addition, they participated in propagating Confucian ideology, as did the village, clan, and guild leaders who also acted as adjuncts to government. These dispute-settlers, however, were not formally responsible to the magistrates, and moreover sought to protect and further their own interests which sometimes conflicted with official interests; clans, villages, and guilds settled disputes among their own members in part to increase their chances of being left alone by the government.

In Communist China, state and society are much more closely integrated. The apparatus of control penetrates much more deeply into Chinese society now than in the past; mediators today are either cadre members of the official apparatus or its activist extensions. The Communist apparatus clearly exercises greater control over China than did its traditional predecessor.

The contrast suggested above is not absolute. Whoever has ruled China from Peking, whether emperor or Chairman Mao, has had to reinforce and supplement an elite with auxiharies. The magistrate was assisted by gentry, village headmen, clan leaders, and other local notables; the cadre is assisted by the activist. In both societies the agents of indirect rule are mediators. This correlation is not accidental, but probably indicates that dispute resolution is ordinarily less important than other affairs of government. The affairs to which pride of place has been given in Imperial and Communist China differ, of course. Yet, because dispute resolution is placed low on the scale of priorities in both traditional and Communist political systems and is handled by auxiliaries in both systems, there is necessarily a similarity between administrative techniques. It would be dangerous to assunie that because the Communists to some extent rule indirectly, they are continuing an old tradition; they are siniply encountering an old problem - the need to rule a huge country with a limited elite-and responding to it by seeking reliable auxiliaries to 
implement policy. The techniques of indirect rule have changed so muchthe auxiliaries are no longer passive agents of the elite, and more mediation is done by the elite itself-that Communist mediation can be said to involve new techniques and values.

In sum, while mediation in traditional China meant and was engaged in for the purpose of avoiding official representatives of the state, mediation in Communist China directly involves representatives of the state. Although both are extrajudicial, traditional mediation was unsupervised by officials, while Communist mediation is conducted and supervised by representatives of the state and the Party. The identity of the mediators and their relations with the rulers of China have changed; consequently, there has been change in the mediators' perception of disputes and how they mediate them.

\section{Different Philosophical and Ideological Attitudes toward Disputes} and Their Resolution

Confucian and Communist views of social conflict present an obvious and dramatic contrast. In the traditional view conflict was a regrettable and possibly dangerous rending of a desired harmonious continuum of relationships. Moreover, conflict, especially face-to-face, was unseemly and embarrassing. Dispute resolution aimed at repairing relationslips rent by the unfortunate occurrence and therefore sought compromise and a reasonable result rather than absolute victory for one party.

Communist ideology not only regards social conflict as inevitable, but considers it the very stuff of social and political process. Individual disputes, while regrettable, are regrettable not so much because they impair the relationships between the disputants, but because they interfere with important national tasks. The Party objective in handling these interferences is not merely to repair damaged relationships or even to improve production, but to use the dispute by resolving the contradictions it represents, "correcting" the disputants" "ideology" and "standpoint," and reaching a result consistent with national policies. These different concepts of disputes have radically changed mediators' views of their role.

\section{Differing Priorities of Dispute Settlement and Didactic Functions}

Althougl mediation in traditional China was considered primarily a mode of settling disputes, it discharged another, very secondary, "didactic" function when mediators instructed disputants, witnesses, and onlookers in the virtues of compromise and other related Confucian virtues. ${ }^{237}$ In Communist China mediation supplements other didactic ad-

237 See I D.F. HENDERSON, supra note 229 , at 4-5. 
ministrative techniques, especially the "mass line," in reinforcing mass commitment to policy. It would be erroneous however, to assume that the Communists have merely reordered the relative priorities of didactic and dispute settlement functions. Rather, they liave sought to change fundamentally the very nature of dispute resolution. The significant reduction of disputants' opportunities to bargain with each other and negotiate for a mutually satisfactory compromise of their disagreement shows clearly the extent of the change.

"Mediation" in traditional China ranged from the lighly informal private attempts of mutual friends to end a dispute to the imposition of a decision by an extremely powerful and respected mediator who "proposed" a solution backed up by very strong public opinion; generally, however, even in a context of powerful group pressures, the traditional mediational style emphasized compromise. Compromise in turn connoted bargaining, and traditional mediation permitted, and was often structured to facilitate, negotiation between the parties. In this way Confucian virtue was supported, group solidarity maintained, and social harmony restored. The parties lost no face either by arrogantly insisting on total victory or encountering total defeat, and tolerable compromises were often reached.

The Communist mediational style is, of course, quite opposed to compromise, which the Party condemns as "unprincipled mediation." The essential Communist notions of contradictions and the need to resolve them through struggle dictate use, rather than avoidance, of face-to-face conflict. Even when the mediator's objective is to induce "self-criticism," the "self-criticism" is more often than not "assisted;" it is much more intense and focused than Confucian self-cultivation and aims at a more active, political result. Communist "self-criticism" should not be confused with Confucian self-cultivation despite occasionally similar rhetoric. ${ }^{238}$ The need to resolve contradictions "correctly" excludes the notion of compromise.

The Communists employ group pressure to instruct individuals in correct behavior and to punish infractions, but the group is much more closely linked with the ruling elite than in Imperial Clina, and that ehte much more overtly manipulates and focuses group pressure. Formerly, group pressure was not in principle opposed to conciliation and compromise. Now the need to resolve contradictions "correctly" and change "thought" excludes compromise. Mediators are required to

238 For an analysis of the psychological pressure to which individuals are subjected, especially through "criticism" and "encouragement". to engage in "self-criticism," sce R. Lifton, Thodght Reform and the Psychology of Totalism (1961); MU Fu-sheno, THE WIITTNG OF THE HUNDREd Flowers 153-59, 208-47 (1962). 
be unyielding when they perceive political and ideological factors in disputes that require "correct" resolution, and one of their tasks is to identify and solve correctly just such factors. Moreover, mediators are encouraged to conduct their duties in the presence of onlookers so that they will be educated together with the disputants. For education to be correct, nothing in the proceedings must confuse or create doubts in the minds of onlookers. As a result, disputants' opportunities to bargain with each other are reduced or eliminated, and there is a smaller chance that the parties to a dispute will obtain redress they consider adequate.

The Coninuunists' emphasis on suppressing bargaining is obviously linked to their use of political standards to settle disputes. The Communists have sought to impose on China an authority structure which depends on and proniotes national values. Traditional mediation reflected and depended on a far more circuniscribed context of highly personal and particularistic relationships. If mediation involved bargaining, bargaining depended on the willingness of disputants and mediators to take into account personal characteristics and to make a highly personal evaluation of the dispute. But the Communists ain at replacing these snialler perspectives with a larger, national perspective. Thus, the authority relationships and the accepted modes of setting disputes upon which traditional and Communist mediation depend are opposed to each other. Cadres lead rather than conciliate; they mobilize rather than instruct. ${ }^{239}$ The Conmunists have sought to repress values such as allegiance to group friendships and personal preferences inconsistent with individuals' obligations to society. ${ }^{240}$ In attempting to change values and the authority relations that maintain then, the Communists have tried to replace mediational bargaining with a mode of dispute settlement that reflects national values and interests. ${ }^{241}$

\section{Differing Relations between Court and Extrajudicial Mediators}

In traditional China, mediation offered disputants a desirable alternative to litigation; for its part, the government welcomed the reduction in the volunie of official work. In Communist China, while the Party has certainly promoted mediation to highten the work load of judicial and nonjudicial cadres, nediation as a mode of dispute resolution no longer differs greatly from the judicial mode. Courts and extrajudicial mediators alike now share the same style of dispute resolution-mobilizational me-

230 F. SCHURManN, supra note 66 , at 8.

240 Vogel, From Friendship to Comradeship: The Change in Personal Relations in Communist China, ChnNA Q., Jan.-Mar. 1965, at 46.

241 See Northrup, supra note 19 , at 360 , arguing correctly that mediation aimed at compromise cannot remain unchanged in a modernizing country in which the modernizers seek to substitute national values for more particularistic ones. 
diation. ${ }^{242}$ As indicated above, the actual attempts of mediators to inject highly political factors into a dispute may vary considerably with the mediation context. It is clear, however, that the Communists have aimed at using mediation of civil cases rather than adjudication in the courts.

\section{CONCLUSION}

Contemporary Chinese dispute resolution seems to owe more to Communist ideology, experience, and practice than it does to Confucian tradition. While there may be "resonances" between traditional and Communist dispute resolution, ${ }^{243}$ the mediational devices used by the Communists seem more directly traceable to their own development as Communists than to the tradition they so resolutely oppose. The Communist Party has had considerable success in altering the nature of courts, unifying judicial and extrajudicial methods of resolving disputes politicizing the mediation process, and, in general, changing and redistributing the functions of mediation. Examination of official Communist objectives and actual practice indicates frequent and substantial correlation between the two. While it may be "tempting" to regard Communist mediators as "successors to the gentry and other prestige figures who settled most of the disputes of village, clan, and guild,"244 it would be dangerous to yield to this temptation. Both the purposes whicl the Communists have assigned to mediation and the mediators and the style they are expected to use in resolving disputes contrast sharply with traditional resolution.

Of course, much investigation remains to be undertaken. This article, in stressing the need to avoid facile comparison between Communist and pre-Communist society and in concentrating on the politicization of Chinese mediation, has perhaps exaggerated Communist innovation. Moreover, this Article draws heavily on sources from the 1950's, althougl more recent sources have been used whenever possible. Fresh information about conditions in China, especially during the past five years, should lead to more sophisticated conclusions on the operation of Communist institutions for dispute resolution, the nature and permanence of Communist change, and the persistence of traditional patterns. In addition, more investigation is needed of possible differences between dispute resolution in rural and urban areas in both traditional and Communist China.

242 Basic Notions on the Work of Mediating Civil Cases at the Second Instance, Political-Legal Research No. 3, at 31 (1959).

243 Cohen, Chinese Mediation, supra note 14, at 1226.

244 Id. Rejection of a "succession" between traditional and Communist mediation does not amount to a refusal to find continuities between the two modes, as should be clear from the selective continuities identified here. 
Further study may be benefited by looking at analogous developments elsewhere. This Article has not compared Chinese dispute resolution with dispute resolution in other modernizing Asian nations, such as Japan and Taiwan, where traditional forms of mediation coexist with elaborate codes of law. ${ }^{245}$ Future comparative inquiry may show the effects on Chinese dispute resolution not only of Maoism, but of forces of modernization common to all developing nations. Recent studies on Taiwan, for instance, indicate that traditional mediation is decaying because land reform and urbanization have disrupted traditional hierarchical relationships and reduced the respect formerly commanded by traditional mediators. ${ }^{246}$

Further inquiry will show more accurately the effects of Chinese Communist imnovation on Chinese society and its means for resolving conflict. Innovation is now only part of the extraordinary revolutionary flux that continues to this day. Whether that flux will eventually give way to traditional practices now only obscured, to other forms which more clearly represent an amalgain of the traditional and the Cominunist, or to still others which resemble Western institutions remains to be seen. In the meantime, this writer can only echo the words of an earher student of Chinese law, who said of his subject, "This is a country not very well explored, and I am an early explorer." ${ }^{247}$

245 For Japan, see 2 D.F. Henderson, supra note 229. For Taiwan, see Regulations on Mediation in Hsiang Market Towns, Jan. 22, 1956, Liu-fa chuan-shu [Complete Book of the Six Laws] (Chang Chin-Pen ed. 1967); B. Gatinn, Hsin Hsing, Tatwan: A Chinese VIILAGE IN CHANGE 185 (1966), describes informal mediation of an intervillage dispute on Taiwan.

246 Gallin, Conflict Resolution in Changing Chinese Society: A Tairwanese Study, in Swartz, Turner \& Tuden, Politicat Antrhropology 265 (1966); Fried, Some Political Aspects of Clanship in a Modern Chinese City, in id. 285 at 298: "This probably is an area of great change, for the clans formerly functioned as quasi-legal courts, keeping disputes out of formal courts. From a traditional posture of avoidance with regard to former legal apparatus, the Chinese, at least those observed on Taiwan, seemed positively litigious. A great volume of cases is being taken to the courts, with a consequent atrophy of the clans' adjudicative functions."

247 Alabaster, Notes on Chinese Law and Practice preceding Revision, 37 J. CHINA Branch, Royal Astatic Society 83, 138 (1906). 


\section{California Law Review}

\begin{tabular}{lll}
\hline \hline Vor. 55 & NOVEMBER 1967 & No. 5 \\
\hline \hline
\end{tabular}

BOARD OF EDITORS

Editor-in-Chief

Peter Kay Westen

Managing Editor

JoHN JACrson BeNTIEX III

Article Editors

AuIson M. Grex

Jomi F. PrITCHARD

Research and Chief Note \& Comment Editor

George Richard Poeminer

Book Review Editor

WIIITAM ROGER STREIOW

Executive Editor

DANIEL U. SMITH

\author{
Note $\mathcal{E}$ Comment Editors \\ PaUl B. Bergman \\ Stephen J. Bisgeter \\ ThMoter Dreyfus \\ Michage C. Ferguson \\ Emren Hatr Gugoentame \\ Donatas Januta \\ Mark Reututuger \\ JefFrey David Sobet \\ WIItrase T. VUROWICH
}

Associate Editors

BrUCE BabCock, JR. JEFEREX F. BECK

WhITAMr S. BETEARD

Lawreayce L. Curtice

Steven H. GoldFarb

SAMVUEL BASSETT ABBotT JAMES ROBERTSON BUTLER, JR. Jamis F. CHRISTIANSEN KENNETH A. COHEN STEVEN W. ERICKSON RICHARD N. FISHER MaX W. J. Grataik, Jr. PaUt Harris

\author{
Robert Earnest Gyemant \\ RTCEARD V. HALI \\ ALAN E. Harris \\ Dougras A. HAydeL \\ JomN E. HuErTa \\ WIItTaMr L. JAEGER
}

\section{Candidates}

JoHn A. Hosknss

RICEARD L. KnNTZ

RICHARD I. LEHER

A. KEITH LESAR

Mtchagr H. Marcus

LEONarb I. Margolis

Robert E. Montgomeri, JR. JOEN K. MORRIS

Patricia A. Muszynski

\section{Secretary}

Susan G. Vega
Brame Covinoton Jantn Mrchaet Justan Myers Dodotas M. ScHWab Janet Frtedman Stansby Kristine Mary Strachan

Clayton C. Patrick Jorn R. PHutrips Jorna M. Poswalt JAMES E. REED Barbara A. RHINe Brent NeIsON RUSEFORTH Stuart P. Tobisman Davio S. WeIssbrobt 